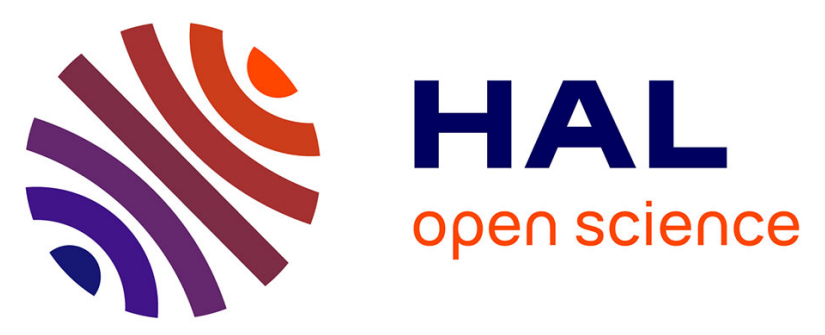

\title{
Micro-scale chemical and physical patterns in an interface of hydrothermal dolomitization reveals the governing transport mechanisms in nature: Case of the Layens anticline, Pyrenees, France
}

Stephen Centrella, Nicolas Beaudoin, Hannelore Derluyn, Geoffrey Motte, Guilhem Hoareau, Pierre Lanari, Francesca Piccoli, Christophe Pécheyran, Jean-Paul Callot

\section{- To cite this version:}

Stephen Centrella, Nicolas Beaudoin, Hannelore Derluyn, Geoffrey Motte, Guilhem Hoareau, et al.. Micro-scale chemical and physical patterns in an interface of hydrothermal dolomitization reveals the governing transport mechanisms in nature: Case of the Layens anticline, Pyrenees, France. Sedimentology, 2021, 68, pp.834-854. 10.1111/sed.12808 . hal-03095041

\section{HAL Id: hal-03095041}

https: / hal-univ-pau.archives-ouvertes.fr/hal-03095041

Submitted on 18 Jan 2022

HAL is a multi-disciplinary open access archive for the deposit and dissemination of scientific research documents, whether they are published or not. The documents may come from teaching and research institutions in France or abroad, or from public or private research centers.
L'archive ouverte pluridisciplinaire HAL, est destinée au dépôt et à la diffusion de documents scientifiques de niveau recherche, publiés ou non, émanant des établissements d'enseignement et de recherche français ou étrangers, des laboratoires publics ou privés. 


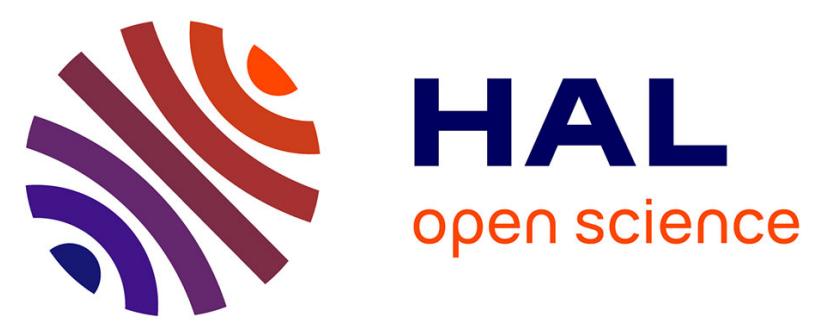

\section{Micro-scale chemical and physical patterns in an interface of hydrothermal dolomitization reveals the governing transport mechanisms in nature: Case of the Layens anticline, Pyrenees, France}

Stephen Centrella, Nicolas Beaudoin, Hannelore Derluyn, Geoffrey Motte, Guilhem Hoareau, Pierre Lanari, Francesca Piccoli, Christophe Pécheyran, Jean-Paul Callot

\section{- To cite this version:}

Stephen Centrella, Nicolas Beaudoin, Hannelore Derluyn, Geoffrey Motte, Guilhem Hoareau, et al.. Micro-scale chemical and physical patterns in an interface of hydrothermal dolomitization reveals the governing transport mechanisms in nature: Case of the Layens anticline, Pyrenees, France. Sedimentology, Blackwell Publishing, 2021, 68 (2), pp.834 - 854. 10.1111/sed.12808 . hal-03252181

\section{HAL Id: hal-03252181}

https: / hal-univ-pau.archives-ouvertes.fr/hal-03252181

Submitted on 7 Jun 2021

HAL is a multi-disciplinary open access archive for the deposit and dissemination of scientific research documents, whether they are published or not. The documents may come from teaching and research institutions in France or abroad, or from public or private research centers.
L'archive ouverte pluridisciplinaire HAL, est destinée au dépôt et à la diffusion de documents scientifiques de niveau recherche, publiés ou non, émanant des établissements d'enseignement et de recherche français ou étrangers, des laboratoires publics ou privés. 
DR. STEPHEN CENTRELLA (Orcid ID : 0000-0002-8856-4286)

Article type : Original Manuscript

Micro-scale chemical and physical patterns in an interface of hydrothermal dolomitization reveals the governing transport mechanisms in nature: case of the Layens anticline, Pyrenees, France

STEPHEN CENTRELLA*, ${ }^{*}$, NICOLAS E. BEAUDOIN* ${ }^{*}$ HANNELORE DERLUYN*, GEOFFREY MOTTE*, GUILHEM HOAREAU*, PIERRE LANARI ${ }^{\ddagger}$, FRANCESCA PICCOLI ${ }^{\ddagger}$, CHRISTOPHE PECHEYRAN ${ }^{\S}$ and JEAN PAUL CALLOT*

*Universite de Pau et des Pays de l'Adour, E2S UPPA, CNRS, TOTAL, LFCR, UMS 3360, Pau, France (E-mail: centrella.stephen@univ-pau.fr)

†Universite de Pau et des Pays de l'Adour, E2S UPPA, CNRS, DMEX, UMR5150, Pau, France Institute of Geological Sciences, University of Bern, Baltzerstrasse 3, CH-3012 Bern, Switzerland. §Universite de Pau et des Pays de l'Adour, E2S UPPA, CNRS, IPREM, UMR 5254, Pau, France

\section{Associate Editor - Hairuo Qing}

Short Title - Hydrothermal dolomitization and transport mechanisms

This article has been accepted for publication and undergone full peer review but has not been through the copyediting, typesetting, pagination and proofreading process, which may lead to differences between this version and the Version of Record. Please cite this article as doi: $\underline{10.1111 / \text { SED } .12808}$

This article is protected by copyright. All rights reserved 


\section{ABSTRACT}

Hydrothermal dolomitization is an important diagenetic process that occurs in tectonic environments worldwide and forms conventional reservoirs associated with ore deposits and hydrocarbon accumulation, while forming efficient reservoirs for carbon sequestration. However, the current state of knowledge about the availability and reaction rate of $\mathrm{Mg}$ in dolomitizing fluids fails to explain the large volumes of hydrothermal dolomites geobodies observed in extended margins or in fold-andthrust belts. To better understand this widespread phenomenon, it is essential to recognize the governing and limiting transport mode of the dolomitizing fluid. This contribution investigates the chemical and physical patterns developed between the original calcite and the newly formed dolomite. An extensive analytical study of well-preserved dolomitization interfaces observed at outcrop scale in Callovian-Oxfordian limestones in the Layens anticline (north-western Pyrenees, France) is presented. Through the use of scanning electron microscopy, electron backscattered diffraction, X-ray microtomography, laser ablation inductively coupled plasma mass spectrometry (and mapping), the replacement related variations in elementary content, rock density, crystallographic properties and phase volumes and distribution were constrained. The results indicate a sequence of replacement, beginning with a fluid which starts to infiltrate the host rock by advection in the grain boundary network causing at the same time the replacement of calcite by diffusion-limited dissolution and associated dolomite precipitation. The progressive replacement of calcite grains by dolomite is led by dissolution inside the grain enhanced by replacement related porosity creation, leading to a progressive decrease of local calcite grain size isolated as islands until the replacement is complete. The replacement of calcite by dolomite led to a mass loss without volume change, through generation of $c a 11$ vol.\% porosity. Based on analytical observations of a natural sample, a conceptual model that accounts for the transport mode governing the different steps of hydrothermal dolomitization at crystal-scale is proposed.

KEYWORDS Dolomitization, fluid-rock interaction, trace element, porosity, replacement.

\section{INTRODUCTION}


Fluid-mediated replacement in rocks is a fundamental process defined as metasomatism, active in the crust, locally altering the mechanical and petrophysical properties of the rocks by changing its mineralogy and chemistry (Putnis, 2009). In the sedimentary diagenetic domain $\left(<250\right.$ to $\left.300^{\circ} \mathrm{C}\right)$, the consequences of replacement are numerous, ranging from fracking (Jamtveit et al., 2000) element cycling in the crust (Whitaker et al., 2004; Ague and Nicolescu, 2014), and variations in reservoir quality for geo-resources and storage (Kirschner \& Barnes, 2009; Thibeau et al., 2013). Dolomitization is a ubiquitous phenomenon of metasomatism in the diagenetic realm (Warren, 2000; Machel, 2004), where carbonate rock $\left(\mathrm{CaCO}_{3}\right)$ interacts with magnesium-rich fluids to form dolomite $\left[\mathrm{CaMg}\left(\mathrm{CO}_{3}\right)_{2}\right]$. There are two main methods of dolomitization. The first relates to early dolomitization, that occurs at low temperature, and is related to either: (i) bacterial activity early after deposition (Slaughter \& Hill, 1991); (ii) specific chemical fluid conditions (Montes-Hernandez et al., 2020); (iii) Mg supersaturation in seawater due to evaporation (reflux mechanism (Nader et al., 2012); or (iv) melange with continental water (Wilson et al., 1990; Gasparrini et al., 2006; Nader et al., 2012). For all of the cases presented above, replacement involves constant renewal by Mg-rich water. The second category relates to late dolomitization, occurring in relationship with an influx of ascending hydrothermal, Mg-heavy evolved fluids that flow and interact with carbonates during tectonism (Swennen et al., 2012; Martín-Martín et al., 2015; Mozafari et al., 2019). The latter is usually referred to as hydrothermal dolomite regardless of the fluid origin (Machel \& Lonnee, 2002), and is of important economic interest (Wallace et al., 1994; Diehl et al., 2010), namely because of a genetic link with base metal deposits (Gomez-Rivas et al., 2014; Kelka et al., 2015; Martín-Martín et al., 2015; Kelka et al., 2017).

To date, the large-scale dolomitization process is still under debate, with remaining questions on the source of fluids and its Mg content (Whitaker et al., 2004; Gomez-Rivas et al., 2014; Koeshidayatullah et al., 2020b) on the pathways allowing for long-term renewed fluid migrations in tectonic context (Machel \& Mountjoy, 1986; Whitaker et al., 2004; Breesch et al., 2010; Beaudoin et al., 2014; Gomez-Rivas et al., 2014; Chen et al., 2016; Pinto et al., 2017; Scribano et al., 2017; Debure et al., 2019; Quesnel et al., 2019), and on the fluid transport limitation of the phenomenon at either outcrop-scale (Koeshidayatullah et al., 2020b) or crystal-scale (Putnis \& Putnis, 2007; Merino and Canals, 2011; Kondratiuk et al., 2015). At the crystal-scale, two conceptual models compete to

This article is protected by copyright. All rights reserved 
account for dolomitization: the growth-driven pressure-solution (Merino \& Canals, 2011); and the dissolution-precipitation mechanism (Putnis \& Putnis, 2007). Dolomite growth-driven pressure solution postulates a $\mathrm{Mg}$-rich/Ca-poor solution that is undersaturated with respect to calcite. This model involves brine infiltration into the limestone, dissolving calcite and supersaturating itself with dolomite. During growth, the same volume of dissolved calcite becomes occupied by dolomite and turns out to be self-accelerating. Dissolution of calcite is controlled by fluid pressure becoming locally higher than the lithostatic pressure and implies a conservation of the solid volume (Merino \& Canals, 2011). Dissolution-precipitation relies on the development of an interconnected porosity allowing the reaction to progress through the crystal/rock. Replacement occurs along the fluid-rock interface and the element exchange is maintained while supplies last (Putnis et al., 2005; Raufaste et al., 2011).

Several experimental studies on calcite/dolomite replacement suggested that the mechanism of dissolution-precipitation is more likely to happen than growth-driven pressure-solution (Machel, 2004; Putnis \& Putnis, 2007; Jonas et al., 2015, 2017; Kondratiuk et al., 2015). This observation is also supported by experimental studies of different systems that are similar to dolomitization (Putnis \& Mezger, 2004; Raufaste et al., 2011; Kar et al., 2015; Renard et al., 2016; Jonas et al., 2017; Beaudoin et al., 2018; Pedrosa et al. 2016a,b). A direct assessment of such processes occurring in natural dolomite is still lacking.

Studies of trace elements in dolomite crystals can bring more details about the process governing the reaction since they are very sensitive to fluid-rock interaction (see chapter 7 in White, 2013). Indeed, the incorporation of trace elements in carbonate minerals might result from a substitution between trace elements, Ca and probably Mg (Abele et al., 1962; Welte, 1962; Deininger, 1964). Consequently, the rare earth element pattern (REE) can help constrain; for example, the source of fluids involved in diagenesis (Haskin \& Gehl, 1962; Piper, 1974; Henderson, 1984) and the redox condition of dolomitizing fluids (Huang et al., 2011; Zhou et al., 2012; Ling et al., 2013; Zhang et al., 2014; Chen et al., 2015).

While dolomitization interfaces are studied at the metre scale to examine the origin and largescale migration mechanisms of dolomitizing fluids (Mozafari et al., 2019; Koeshidayatullah et al., 2020a), a detailed study of microstructural and chemical patterns at the scale of a natural limestone 
partially replaced by dolomite has never been reported. Yet, this study can validate insights from experiments and can suggest governing mechanisms of fluid transport at a small scale that undoubtably impacts the larger-scale expression of the dolomitization. This study reports an analytical and textural study of a natural replacement front comprised of both original calcite and transformed dolomite from the Layens anticline, located in the north Pyrenean foreland (France). Based on X-ray microtomography (X-ray $\mu \mathrm{CT}$ ), scanning electron microscopy (SEM) and electron back scattered diffraction (EBSD), it is possible to quantify phase proportions across the calcite-dolomite transition, and to see where dolomite is located in the rock (in three-dimensions) to characterize which mechanism is associated with the dolomitization reaction. The extent of mass transport has been determined to understand mass redistribution across the calcite-dolomite transition using an electron probe micro-analyzer (EPMA), femto laser ablation inductively coupled plasma mass spectrometry (fs-ICP-MS) and laser ablation ICP-MS (LA-ICP-MS), X-ray $\mu \mathrm{CT}$ and mass balance equations. All of this led to establishment of the steps that affected the rock at crystal-scale during dolomitization, with a special emphasis on transport mode, fluid pathways and chemical exchanges between the fluid and rock.

\section{GEOLOGICAL SETTING}

Preserved dolomitization fronts were recognized in the Layens anticline, located in the northern Pyrenean zone (Fig. 1). This anticline is part of the Chaînons Béarnais, a sequence of three overturned anticlines with an east-west strike parallel to the Pyrenees chain (Labaume \& Teixell, 2020). From the Triassic to the Jurassic, the opening of the Atlantic Ocean might have developed a normal fault network (Puigdefàbregas \& Souquet, 1986). An extensional event started in the early Cretaceous with the formation of a rift (Tugend et al., 2015; Teixell et al., 2016). During this period of extension, the depocentres were affected by major faulting developing tilted blocks at both kilometre and metre scales, leading eventually to the formation of one or several detachment faults that caused mantle exhumation (Lagabrielle et al., 2010; Masini et al., 2014). At the same time, the sedimentary succession was deformed and folded by the formation of salt diapirs (Triassic), including the Layens area (Izquierdo-Llavall et al., 2020; Labaume \& Teixell, 2020). This period was followed by a compressive event and a continental collision which started in the late Santonian (ca $80 \mathrm{Ma}$ ) and

This article is protected by copyright. All rights reserved 
culminated in the middle Tertiary forming the present day antiformal stack of the Pyrenean belt (Mouthereau et al., 2014; Teixell et al., 2016).

Stratigraphy of the Layens anticline is extensively documented elsewhere (Lenoble, 1992: James, 1998). The sedimentary column starts with evaporites and marls (Keuper Marls, Upper Triassic), overlaid by interbedded marls and limestones (Aussurucq Limestones, Lias), partially dolomitized bioclastic limestone (Meillon Formation, Callovian-Oxfordian) and argillaceous limestones (Lons Limestones, Oxfordian-Kimmeridgian). This sequence is overlain unconformably by reef limestones (Lenoble, 1992). Published palaeofluid characterization relates the regional dolomitization of the Meillon Formation to a flow of hydrothermal magmatic fluids that became hypersaline in contact with Triassic evaporites, ascending along faults (Salardon et al., 2017). The dolomitization event is synchronous with Albian-Cenomanian rifting and associated crustal thinning (Salardon et al., 2017; Incerpi et al., 2020), with a geothermal gradient around $c a 80^{\circ} \mathrm{C} / \mathrm{km}$ (Vacherat et al., 2014).

The studied calcite-dolomite interface was sampled in the Meillon Formation $\left(43^{\circ} 01^{\prime} 11.9^{\prime \prime} \mathrm{N}\right.$, $\left.0^{\circ} 39^{\prime} 15.3^{\prime \prime} \mathrm{W}\right)$. The distribution of the dolomite documented in the Meillon Formation cropping out in the Layens anticline is bound to the distribution of normal faults, but the contacts between dolostone and limestone are easily visible on the field (Figs 2A, 2B and S1). Most of the contacts are marked by the presence of pressure-solution figures (i.e. stylolites) and the absence of a gradient between the host limestone and the newly formed dolomite (Fig. 2B).

\section{ANALYTICAL METHODS}

\section{Sample description and preparation}

Hand specimens of transition zones between the limestone and dolostone were collected in the field, and those exhibiting the wider and more gradual transition zone at their surface were selected for further investigations (supplementary material). Because samples display a transition zone affected by pressure-solution, in situ analysis focussed on a single sample that exhibited the most preserved, complete record of the interface (Fig. 2C). Three polished thin sections $(60 \times 45 \mathrm{~mm})$ were prepared across the entire hand specimen from the original calcite to the dolomite domain. Petrological characterization under optical microscopy (Nikon Eclipse LV100ND; Nikon, Tokyo, Japan) was 
carried out at the Laboratory of Complex Fluids and their Reservoirs (LFCR) at the University of Pau and Pays de 1'Adour, (UPPA) Pau, France.

\section{Phase characterization and distribution using X-ray tomography}

A 3D quantitative characterization of the morphology and distribution of elements forming the rock was performed using X-ray computed microtomography $(\mu \mathrm{CT})$. This technique was employed to quantify the local modal abundance of mineral phases across the replacement front. Four cores $4 \mathrm{~mm}$ in diameter and $1.3 \mathrm{~cm}$ long were drilled, corresponding to the different zones observed across the hand specimen. The $\mu \mathrm{CT}$ scans were acquired on a Zeiss Xradia Versa 510 (Zeiss, Oberkochen, Germany) located at the Experimental X-Ray Methodology Development (DMEX, UPPA). To ensure an optimal voxel size, each core was scanned in four parts, and then the parts were stitched together. The resulting datasets, hereinafter referred to as scans, cover the full sample heights. All scans were acquired at a voltage of $80 \mathrm{keV}$ and a power of $7 \mathrm{~W}$ with a magnification resulting in a pixel size of $2.65 \mu \mathrm{m}$ (corresponding to voxel of $18.61 \mu \mathrm{m}^{3}$, scans 1,3 and 4 ) and $3.75 \mu \mathrm{m}$ (voxel size of 52.73 $\mu \mathrm{m}^{3}$, scan 2). The core in scan 2 consists of coarser grains so it has a $3.75 \mu \mathrm{m}$ pixel size; some spatial resolution was sacrificed to keep the scanning time within a reasonable time frame for this sample. This sample attenuated X-rays more strongly, possibly due to a local variation in porosity and density. A total of 1601 projections were taken for each scan. The same exposure times were adjusted for each core (between $5.5 \mathrm{~s}, 8 \mathrm{~s}$ and $10 \mathrm{~s}$ ) to maximize the signal to noise ratio. Volumes were reconstructed using a standard filtered back projection reconstruction algorithm (Ramachandran \& Lakshminarayanan, 1971; Feldkamp et al., 1984). Image processing was carried out with the proprietary image analysis software Dragonfly v.3.6.1.492. (C) 2020 Object Research Systems (ORS)

Inc. The remaining noise was filtered using a median filter (Kernel size 3). The data were manually segmented into four phases based on their greyscale values after BSE (backscattered electron) and EPMA (electron probe microanalyzer) control (Fig. 3). The greyscale values reflect the X-ray attenuation, which is function of a combination of the mean atomic number and density of the target material in function of the polychromatic X-ray spectrum. The post-processing quantification of all the features characterized, neglect anything smaller than 5 voxels, so less than $93 \mu \mathrm{m}^{3}$ for a pixel size of $2.65 \mu \mathrm{m}$ (or a voxel of $18.61 \mu \mathrm{m}^{3}$ ) and less than $263 \mu \mathrm{m}^{3}$ for a pixel size of $3.75 \mu \mathrm{m}$ (or a voxel of

This article is protected by copyright. All rights reserved 
$52.73 \mu \mathrm{m}^{3}$ ). The volume selected to extract the phase proportions was of $1 \mathrm{~mm}^{3}$ to avoid overestimating the porosity and oxide fractions. This volume is at least two orders of magnitude higher than the biggest pore and the maximum grain size of oxides. The uncertainties on the phase proportion have been estimated by variation of threshold and by adding/removing a one-voxel thick layer on every cluster of voxels. The variation on phase proportion before and after the tow operations corresponds to the uncertainties.

\section{Crystallographic analysis}

Electron backscatter diffraction (EBSD) analysis was carried out at the Centre de MicroCaractérisation Raimond Castaing, Toulouse, using a JEOL JSM-7100TTLS LV (JEOL Limited, Tokyo, Japan). Electron backscatter diffraction data were acquired using an Oxford Instruments Aztec 3.4 EBSD and energy-dispersive X-ray spectroscopy (EDS) system (Oxford Instruments, Abingdon, UK) using an accelerating voltage of $20 \mathrm{keV}$ and a beam size of $10 \mu \mathrm{m}$. Postprocessing of EBSD data was done using HKL Oxford(C) Instruments Channel 5 v.5.12.72.0 software. A replacement of single pixels that were different (by some misorientation) from six nearest neighbours was applied. The change in the lattice parameters between calcite and dolomite due to band shifts make the phase separation difficult. Energy-dispersive X-ray spectroscopy mapping was used to separate calcite and dolomite with respect to $\mathrm{Mg} / \mathrm{Ca}>1$ for dolomite and $\mathrm{Mg} / \mathrm{Ca}<1$ for calcite (Pearce et al., 2013).

\section{Major elementary content}

Major element compositions of calcite and dolomite were obtained using a JEOL JXA-8200 superprobe at the Institute of Geological Sciences, University of Bern (Switzerland). Analytical conditions were $1.5 \mathrm{nA}$ beam current and $15 \mathrm{keV}$ accelerative voltage and a beam size of $10 \mu \mathrm{m}$ to ensure stability of the material during the analysis. Calibration was performed using the CITZAF routine (quantitative matrix correction) with natural and synthetic standards: dolomite ( $\mathrm{Mg})$, calcite $(\mathrm{Ca})$, tephroite $(\mathrm{Mn})$ and siderite $(\mathrm{Fe})$.

\section{Trace element concentration}

This article is protected by copyright. All rights reserved 
Trace element data were collected using two different laser ablation setups. The first one was a Resonetics RESOlutionSE $193 \mathrm{~nm}$ excimer laser system (Resonetics, Nashua, NH, USA) equipped with a S-155 large volume constant geometry chamber (Laurin Technic, Australia) at the Institute of Geological Sciences, University of Bern (Switzerland). The laser system was coupled to an Agilent 7900 quadrupole ICP-MS instrument (Agilent Scientific Instruments, Santa Clara, CA, USA). Samples were ablated in a He atmosphere and the aerosol was mixed with Ar carrier gas before being transported to the ICP-MS. The ICP-MS was tuned for low oxide production $(\mathrm{ThO} / \mathrm{Th}<0.2 \%)$ and $\mathrm{Th} / \mathrm{U}$ ratio close to one. Laser spots were ablated at $5 \mathrm{~Hz}$ using an $80 \mu \mathrm{m}$ beam diameter and a flux of $5 \mathrm{~J} / \mathrm{cm}^{2}$. The analyzed surface was cleaned by pre-ablation by three laser pulses employing a larger spot size. The total acquisition time for each analysis was $70 \mathrm{~s}$, consisting of $30 \mathrm{~s}$ of gas background acquired with the laser switched off, $10 \mathrm{~s}$ of washout after pre-ablation cleaning and $30 \mathrm{~s}$ of ablation signal. Dwell times were $8 \mathrm{~ms}$ for ${ }^{23} \mathrm{Na},{ }^{24} \mathrm{Mg},{ }^{44} \mathrm{Ca},{ }^{27} \mathrm{Al}$ and ${ }^{39} \mathrm{~K} ; 20 \mathrm{~ms}$ for rare earth elements (REE), ${ }^{208} \mathrm{~Pb}$ and ${ }^{238} \mathrm{U}$; and $10 \mathrm{~ms}$ for ${ }^{7} \mathrm{Li},{ }^{9} \mathrm{Be},{ }^{11} \mathrm{~B},{ }^{45} \mathrm{Sc},{ }^{49} \mathrm{Ti},{ }^{51} \mathrm{~V},{ }^{53} \mathrm{Cr},{ }^{54-55-56} \mathrm{Fe},{ }^{55} \mathrm{Mn},{ }^{61} \mathrm{Ni},{ }^{66} \mathrm{Zn}$, ${ }^{75} \mathrm{As},{ }^{85} \mathrm{Rb},{ }^{88} \mathrm{Sr},{ }^{89} \mathrm{Y},{ }^{111} \mathrm{Cd},{ }^{133} \mathrm{Cs},{ }^{137} \mathrm{Ba}$ and ${ }^{232} \mathrm{Th}$. External calibration was performed using trace element doped basaltic glasses GSD-1g (Jochum et al., 2010) and NIST 612 (Jochum et al., 2011) from the USGS, employing the preferred values listed in Peters \& Pettke (2017), and ${ }^{44} \mathrm{Ca}$ and ${ }^{24} \mathrm{Mg}$ as internal standards (for calcite and dolomite, respectively). The concentrations obtained by EPMA were used for the calibration of LA-ICP-MS data. Data were reduced employing Iolite (Paton et al., 2011).

The second setup consisted of a femtosecond laser ablation system (Lambda3; Nexeya, Bordeaux, France) coupled to a high resolution ICP-MS (HR-ICP-MS) Element XR fitted with the Jet Interface (fsLA/HR-ICP-MS) (Thermo Fisher Scientific, Waltham, MA, USA). The laser is fitted with a diode-pumped Yb:KGW crystal laser source (HP2, Amplitude Systèmes, Pessac, France). Pulse duration is less than $400 \mathrm{fs}$ at $257 \mathrm{~nm}$. The laser source can operate within a wide range of repetition rates $(1 \mathrm{~Hz}$ to $100 \mathrm{kHz}$ ) and energy ranging from $200 \mu \mathrm{J}$ per pulse below $1 \mathrm{kHz}$ to $1 \mu \mathrm{J}$ at $100 \mathrm{kHz}$ at $257 \mathrm{~nm}$. Complex trajectories can be realized by moving the laser beam (15 $\mu \mathrm{m}$ diameter at full energy) across the surface of the sample using the rapid movement of galvanometric scanners combined with a high repetition rate (Aramendía et al., 2015; Donard et al., 2017).

This article is protected by copyright. All rights reserved 
The aerosol produced by the ablation was carried to the ICP-MS by a tube (1/16" internal diameter) using a He stream $\left(600 \mathrm{~mL} / \mathrm{min}^{1}\right)$ leading to a measured wash out time of the ablation cell of $c$ a $500 \mathrm{~ms} .10 \mathrm{~mL} / \mathrm{min}^{1}$ of nitrogen was added to the He flow before mixing with argon in the ICPMS in order to improve the signal sensitivity. Measurements were performed under dry plasma conditions. The fsLA-ICP-MS coupling was tuned on a daily basis in order to achieve the best compromise in terms of sensitivity, accuracy, particle atomization efficiency and stability. The additional Ar carrier gas flow rate, torch position and power were adjusted so that the U/Th ratio was close to $1 \pm 0.05$ when ablating the glass SRM NIST612. NIST612 and NIST610 were used for calibration standard and ${ }^{43} \mathrm{Ca}$ was used as internal standards (Jochum et al., 2011). Detector crosscalibration and mass bias calibration were checked daily using the appropriate sequence of the Element Software. ${ }^{25} \mathrm{Mg},{ }^{35} \mathrm{Cl},{ }^{43} \mathrm{Ca},{ }^{51} \mathrm{~V},{ }^{66} \mathrm{Zn},{ }^{85} \mathrm{Rb},{ }^{88} \mathrm{Sr},{ }^{89} \mathrm{Y},{ }^{139} \mathrm{La},{ }^{140} \mathrm{Ce},{ }^{141} \mathrm{Pr},{ }^{146} \mathrm{Nd},{ }^{150} \mathrm{Sm},{ }^{153} \mathrm{Eu}$, ${ }^{158} \mathrm{Gd},{ }^{159} \mathrm{~Tb},{ }^{163} \mathrm{Dy},{ }^{165} \mathrm{Ho},{ }^{166} \mathrm{Er},{ }^{169} \mathrm{Tm},{ }^{172} \mathrm{Yb},{ }^{175} \mathrm{Lu},{ }^{208} \mathrm{~Pb}$ and ${ }^{238} \mathrm{U}$ were selected in low resolution mode $(\mathrm{R}=300)$ with a dwell time of $30 \mathrm{~ms}$.

Images were built from the fsLA/HR-ICP-MS signal resulting from the sample's ablation according to a series of horizontal lines vertically distributed with $20 \mu \mathrm{m}$ spacing (centre to centre). Taking into account that the washout time of the laser cell (based on $99 \%$ criterion) was about $0.5 \mathrm{~s}$ and the ICP-MS was set to acquire 0.84 point per second, the sample translation was set to $9 \mu \mathrm{m} . \mathrm{s}^{-1}$ and the space between lines was set to $20 \mu \mathrm{m}$ in order to obtain square pixels of $20 \times 20 \mu \mathrm{m}$. In other words, the image resolution was set to $20 \mu \mathrm{m}$. In these conditions the signal corresponding to $5.2 \times 2.2 \mathrm{~mm}$ was acquired in 9.5 hours.

\section{RESULTS}

\section{Petrology}

The studied specimen is characterized by three main parts: (i) the original (non-reacted) rock consisting of small-sized ( $<$ millimetre) crystalline calcite (Fig. 2C, left-hand side); (ii) a calcitedolomite transition consisting of $c a 2.5 \mathrm{~cm}$ of coarse calcite (millimetre) and $c a 0.5 \mathrm{~cm}$ of fine calcite ( $<$ millimetre) (Fig. 2C, centre); (iii) the replaced rock consists of small-size $(<$ millimetre) nonpervasive euhedral crystal of dolomite. A pressure-solution zone, marked by stylolites, separates the calcite domain (dashed line on left, Fig. 2C). Strikingly, contacts between the three parts described 
before are parallel to one another (dashed lines, Fig. 2C). In the calcite-dolomite transition part, a zebra-like alternation of darker and lighter calcite stripes appears oriented parallel to the contact with the calcite (Fig. 2D and E).

\section{Phase characterization and distribution}

Three mineral phases plus the porosity were segmented by $\mu \mathrm{CT}$ based on distinct ranges of grey values (Fig. 3), in line with the results of the SEM-EDS-EPMA analysis (Fig. 4). The following progression goes from the lower range of grey values to the highest: porosity, dolomite, calcite and oxides. Dolomite appears darker than calcite on the $\mu \mathrm{CT}$ volumes suggesting the presence of an intragranular porosity within dolomite below the threshold of resolution of $\mu \mathrm{CT}$ (Fig. 4).

The integration of EBSD data with the volume fraction obtained by $\mu \mathrm{CT}$ allowed to define four zones across the sample (Fig. 5).

1 Original calcite. Grains exhibit a constant size around $100 \mu \mathrm{m}$ in diameter, a low porosity $(0.5$ to 1.0 vol.\%) and oxides located along the grain boundaries (Fig. 4A). Stylolites are present at the contact with the calcite-dolomite transition.

2 Reaction zone A. Calcite grains are larger, between $200 \mu \mathrm{m}$ and $1.5 \mathrm{~mm}$ in diameter, with a low porosity $(<0.5$ vol. $\%)$ and some oxide inclusions. Oxides and porosity are located along the grain boundary network (Fig. 4B). All oxides represent $c a 0.1$ vol.\%. Dolomite is present at grain boundaries $(<1$ vol.\%).

3 Reaction zone $B$. This zone is depleted in calcite and enriched in dolomite compared to zone A. The porosity is higher $(>0.5$ vol. $\%)$ and appears within calcite and dolomite grains and along grain boundaries (Fig. 4B to D). The grain size of calcite decreases from $300 \mu \mathrm{m}$ to less than $50 \mu \mathrm{m}$ across zone B towards the dolomite on the right. Oxide abundance is higher when compared to zone A ( $c a$ 0.7 vol. \%).

4 Dolomite domain. This domain exhibits a progressive increase in crystal size away from reaction zone B. Porosity and oxides contents are constant throughout the domain ( $c a 2$ vol.\% and $c a$ 0.1 vol. $\%$, respectively).

This article is protected by copyright. All rights reserved 
Neither calcite nor dolomite shows a crystallographic preferred orientation in the subsets of $c a 5 \mathrm{~mm}^{2}$ across the sample (Fig. S2). The volume of porosity is constant across the four zones within the analytical uncertainties. The grain size of calcite and dolomite change gradually in opposition from reaction zone A to the dolomite domain (Fig. S3). The uncertainties on the phase proportion (by variation of threshold and by adding one layer of voxel) is around 14 vol.\% for the dominant phase (calcite and dolomite) and less than 1 vol.\% for the oxides and the porosity.

The $3 \mathrm{D}$ distribution of dolomite and porosity in reaction zone $\mathrm{A}$ is shown in Fig. 6A. The calcite grains (low opacity) are partially dolomitized. Dolomite (in black) is associated with the porosity (red) in the grain boundary region and within the calcite grains. When the replacement is more advanced (for example, reaction zone B), the grains of calcite become more and more isolated from one another, and dolomite is distributed in the crystal in dendrite-like channels (Fig. 6B and C).

\section{Mineral chemistry}

The major element composition of both calcite and dolomite is uniform throughout the sample, with a composition close to pure calcite and pure dolomite (Table S1). In detail, original calcite Mg content ranges between 0.13 to 0.31 wt.\%, with nearly no $\mathrm{Mn}$ nor $\mathrm{Fe}(<0.03$ wt.\% in total). Magnesium content in calcite in the reaction zone ranges between 0 to 0.43 wt.\% with nearly no $\mathrm{Mn}$ or $\mathrm{Fe}$ (less than 0.03 wt.\%). Dolomite contains less than 0.1 wt.\% Fe and Mn. Hematite is the only oxide detected in the hand specimen. The concentrations in trace element are variable between the original calcite and the calcite located in the calcite-dolomite transition at 2 se (two standard errors, Fig. 7; Table S1). The REE pattern of original calcite is slightly negative, with a relative enrichment in heavy REEs (HREE: Tb to $\mathrm{Lu}$ ) compared to light REEs (La to $\mathrm{Gd}$ ). This important variation is due to the presence of small grains, porosity and small oxides (visible with in BSE) compared to the laser beam size $(80 \mu \mathrm{m})$. Calcite in the reaction zone has a relatively flat REE pattern, with higher LREE content compared to the original calcite. A positive Eu anomaly in the two calcites is present. Dolomite has a REE pattern comparable to that of the original calcite, though with slightly higher La, Ce, Pr and $\mathrm{Nd}$ concentration and slightly lower HREE content. A similar decrease in Tm content in calcite from the reaction zone is also observed. The major differences in trace element content are observed for $\mathrm{U}, \mathrm{Zn}$, $\mathrm{Ba}, \mathrm{Na}, \mathrm{V}, \mathrm{Cr}$ and Sr (Table S2). 
Trace element maps were collected in the calcite-dolomite transition zone A to visualize the redistribution of trace elements between calcite and dolomite and possible heterogeneities (Fig. 8). It corresponds to scan 2 used for X-ray $\mu \mathrm{CT}$. Image segmentation was performed based on pixel densities using the Binary module of XMapTools 3.3.1 (Lanari et al., 2014, 2019). The 'mixed' phase (Fig. 8A) corresponds to pixels with intermediate compositions between calcite and dolomite. The group containing these pixels is closer in composition to the dolomite (purple, Fig. 8). Oxides (red, Fig. 8A) are located at the grain boundaries of calcites and have the highest concentration of $\mathrm{Zn}$ and $\mathrm{Pb}$ (Fig. 8B and C).

\section{INTERPRETATION}

\section{Origin of dolomitization}

The regional dolomitization of the Meillon Formation could be related to an infill of hydrothermal hypersaline fluids flowing along faults related to Cretaceous rifting and associated with crustal thinning (Salardon et al., 2017; Incerpi et al., 2020), leading to a geothermal gradient of $c a 80^{\circ} \mathrm{C} / \mathrm{km}$ (Vacherat et al., 2014). However, no fluid temperature data were collected in the Layens anticline because all observed fluid inclusions are below $5 \mu \mathrm{m}$. It is proposed that chemical and crystallographic patterns documented in the calcite-dolomite interface are an indirect validation of the hydrothermal origin of the dolomite of the Meillon Formation. Indeed, an alternation between lighter and darker stripes in thin section shown in Fig. 2D is similar to the zebra texture that is typical of base metal ore deposits $(\mathrm{Zn}-\mathrm{Pb})$ linked to hydrothermal dolomite formations (Leach \& Viets, 1992; ; Wallace et al., 1994; Krug et al., 1996; Paradis et al., 2007; Palinkaš et al., 2009; Diehl et al., 2010; Kelka et al., 2015, 2017; Kelka, 2017). The zebra pattern indicates that the original calcite experienced recrystallization and coarsening prior to or during the early dolomitization stage. Such a recrystallization process can be related to either fluid pressure or stress waves linked to a first step of fluid infiltration, and/or to stress around fracture zones (Kelka et al., 2015, 2017; Centrella et al., 2018). Trace element maps (Fig. 8) show that, in the transition zones A and B, oxides and dolomite are located at grain boundaries, both with higher concentrations of $\mathrm{Zn}$ and $\mathrm{Pb}$ than in calcite (Fig. 8; Table S2). Additionally, redox conditions of dolomitization are obtained using trace elements such as Mn, V and U (Huang et al., 2011; Zhou et al., 2012; Ling et al., 2013; Zhang et al., 2014; Chen et al., 
2015). These three elements are more concentrated in dolomite, assuming a general reduced environment, again similar to base metal ore deposits (Zhong et al., 2015).

In the absence of available microthermometric data it is difficult to estimate the temperature formation of dolomite in order to confirm the hydrothermal fluid argument. This can be done using a succession of observations: the documentation anywhere else of proto-zebra-like patterns in poorly transformed calcite in a reduced environment coupled to higher concentrations of base metals in the dolomite precipitated at the grain boundaries suggests that the dolomitization of the Meillon Formation in the Layens is related to a hydrothermal fluid flow, likely linked to the magmatic fluid flow documented regionally (Salardon et al., 2017).

\section{Mass change during dolomitization}

Mass balance calculations can be used to quantify element mobility during fluid-induced reactions (Ague, 1991; Centrella et al., 2015, 2016, 2018; Centrella, 2019), but knowledge of local density and specific volume changes is required. Following Gresens (1967), the overall element gain/loss ratio during replacement of calcite by dolomite can be evaluated as function of the solid volume variation $\left(\Delta \mathrm{V}_{\text {reaction }}\right.$, Fig. $\left.9 \mathrm{~A}\right)$ :

$$
f v\left(\frac{g_{D o l}}{g_{C a l}}\right) \times c_{n}^{D o l}-c_{n}^{C a l}=x_{n}
$$

With $f v$ as the volume factor further converted to volume change $\left(\Delta \mathrm{V}_{\text {reaction }}\right)$. For example, a volume factor of 0.9 corresponds to $10 \%$ volume loss. The quantities $g_{D o l}$ and $g_{C a l}$ are the density of dolomite and calcite respectively, $c_{n}^{D o l}$ and $c_{n}^{C a l}$ the weight fractions of component $n$ in minerals whereas $x_{n}$ represents the gain or the loss for each component.

The selected average composition for the calcite is the one located in the reaction zone because dolomite is missing in the original calcite domain on the left side of the stylolite (Fig. 2). The average composition for the dolomite corresponds to the fully transformed zone for dolomite. Both minerals are close to the pure end-member compositions (oxide weight percentage, Table S1). Consequently, theoretical values of $2.71 \mathrm{~g} / \mathrm{cm}^{3}$ for $g_{D o l}$ and $2.84 \mathrm{~g} / \mathrm{cm}^{3}$ for $g_{C a l}$ (Steinfink \& Sans, 1959; Graf, 1961) can be used in Eq. 1. For the average calcite and dolomite composition, the weight 
fraction of $\mathrm{CO}_{2}$ in calcite and dolomite was not measured with the analytical techniques employed. They were approached by a difference between the expected total oxide weight percent (i.e. 100 wt.\%) and the sum of the values obtained for all measured elements (i.e. $53.35 \mathrm{wt} \%$ for calcite and $49.82 \mathrm{wt} . \%$ for dolomite), giving dolomite $c_{\mathrm{CO} 2}^{\mathrm{Dol}}$ of $50.18 \mathrm{wt} . \%$ and calcite $c_{\mathrm{CO} 2}^{\mathrm{Cal}}$ of $46.65 \mathrm{wt} . \%$. The $\Delta \mathrm{V}_{\text {reaction }}$ can be approximated either by assuming one element to be immobile or by minimizing the flux of mass transfer (Hermann et al., 2013). Since it is difficult to know for any reaction which element could be immobile (Ague, 1994), the second method of minimizing the mass transfer was favoured (Fig. 9B). This method sums the masses (elements) from the reactant and the product for different $\Delta \mathrm{V}_{\text {reaction }}$ and selects the $\Delta \mathrm{V}_{\text {reaction }}$ where the sum is the lowest. Calculations in this study show that for measured concentrations, the mass transfer occurring during replacement of calcite by dolomite is a minimum of a $\Delta \mathrm{V}_{\text {reaction }}$ of $c a-11 \%$; i.e. the volume of solid is reduced by $11 \%$ (Fig. 9B). The effect of the uncertainty for both calcite and dolomite densities is negligible. if considering a variation of $5 \%$ and the $\Delta \mathrm{V}_{\text {reaction }}$ change is less than $1 \%$, these are neglected in the following discussion. Note that using pure end-member calcite and dolomite compositions results in a slightly lower $\Delta \mathrm{V}_{\text {reaction }}$ of $-16 \%$. This shows that the consideration of $\mathrm{Fe}$ and $\mathrm{Mn}$ in the mineral composition

changes the $\Delta \mathrm{V}_{\text {reaction }}$ by about $5 \%$ with respect to pure calcite and dolomite compositions. In terms of mass transfer, and still assuming a $\Delta \mathrm{V}_{\text {reaction }}$ of $-11 \%$, the calcite to dolomite reaction can be written as follows:

$$
\begin{aligned}
& 100 \mathrm{~g} \text { of calcite }+0.02 \mathrm{~g} \mathrm{FeO}+19.19 \mathrm{~g} \mathrm{MgO}+0.01 \mathrm{~g} \mathrm{CO}_{2}=93.13 \mathrm{~g} \text { of dolomite }+ \\
& 0.004 \mathrm{~g} \mathrm{MnO}+26.09 \mathrm{~g} \mathrm{CaO}
\end{aligned}
$$

In this model, only $93.13 \mathrm{~g}$ of dolomite is made from $100 \mathrm{~g}$ of original calcite, resulting in $7 \mathrm{wt} \% \mathrm{of}$ net mass loss that needs to be extracted by the fluid phase. Considering the respective phase proportion across the reaction zones A and B and the mass balance (Eq. 2), a profile of mass change can be simulated (Fig. 9C). In reaction zone A, the mass variation is not significant whereas in reaction zone $\mathrm{B}$, the mass drops to reach $\mathrm{ca} 7 \%$ of mass loss.

Mass balance calculations can also be made with trace elements since the pattern between the calcite in reaction zone and the dolomite (REE) is similar (Fig. 10A) (Centrella et al., 2016; Ague, 
2017). During dolomitization, LREE are fractionated rather than HREE. From La to Nd, ca $40 \%$ of mass is lost. Europium is the element that has been the most leached during dolomitization with $72 \%$ of mass loss. The average gain and loss of all REE gives $40 \%$ of mass loss during dolomitization of calcite. Other diagnostic trace elements are presented in Fig. 10B.

\section{DISCUSSION: CONCEPTUAL MODEL FOR HYDROTHERMAL DOLOMITIZATION}

Hydrothermal dolomitization is a multi-scale problem, with competing replacement models occurring at the crystal-scale [dissolution precipitation sensu Putnis \& Putnis (2007), growth driven pressure solution sensu Merino \& Canals (2011)] and conceptual models of large-scale fluid flow and recharges (Gomez-Rivas et al., 2014; Mozafari et al., 2019; Koeshidayatullah et al., 2020a,b). The Meillon Formation in the Layens anticline, north Pyrenees, exhibits a rare occurrence of a sequence of partial replacement fossilized at the outcrop scale, giving an alternate and complementary view of published dolomitization front studies at the metre-scale, that deals with larger scale fluid dynamics (Koeshidayatullah et al., 2020b). The steps of replacement are inferred from analytical, morphological and chemical analyses performed across the transition from calcite to dolomite. From the analyses of the two main reaction zones observed in the transition zone, a generic model with specific constraints over the factors and transport mechanisms that control elementary exchange between fluid and rock (Fig. 11) is proposed. Figure 11 illustrates the schematic replacement sequence starting by fluid infiltration in the host limestone, by advection channelized along grain boundaries (Fig. 11B). This type of replacement by advective transport is commonly evoked to explain the general wavy morphology of the replacement front (Fig. 2A) (Szymczak \& Ladd, 2006, 2014; Kondratiuk et al., 2015; Beaudoin et al., 2018). The subsequent reaction with calcite grains seemingly involves calcite dissolution, as witnessed by identified micro-scale dendrite-like patterns (Fig. 6B and C), symptomatic of dissolution in granular media (Golfier et al., 2002; Eriksen et al., 2015; Xu et al., 2018). It is proposed that the calcite is dissolved, releasing elements like $\mathrm{Sr}, \mathrm{Ca}$, LREE through the fluids, and is replaced simultaneously by dolomite, in a diffusion-limited process. This is an observation that is in accordance with experimental findings (Jonas et al., 2015, 2017) and allows for the transfer of fluid transport and of dissolution-precipitation mechanisms from the experimental to natural diagenetic domain. As a function of how the system is open to mass transfer, localized stress

This article is protected by copyright. All rights reserved 
can be generated during the reaction as a result of local density changes in the solid system (Wheeler, 1987; Ague, 1991, 1994; Jamtveit et al., 2000, 2008; Jamtveit \& Hammer, 2012; Kelemen \& Hirth, 2012; Centrella et al., 2015, 2016, 2018; Centrella, 2019). In the case of dolomite replacing calcite, density increases by about 5\% (Steinfink \& Sans, 1959; Graf, 1961) meaning that the volume of the solid phase decreases. If the overall volume stays constant, porosity is generated to compensate for the density increase. Multiple experiments show this porosity generation when a single phase is replaced by a denser one (Putnis, 2002; Putnis \& Putnis, 2007; Ruiz-Agudo et al., 2014; Pedrosa et al. 2016a,b). The porosity is not only a consequence of a reduction in solid molar volume but dependent on the relative solubilities of parent and product solid phases in the reactive fluid. More of the parent material may be dissolved than the product re-precipitated thus generating porosity. With the generated nanometre-scale to micron-scale porosity, dissolution-precipitation progresses in the crystal and isolated calcite islands from each other (reaction zone B, Fig. 11D and E), until the crystals are completely replaced by dolomite.

\section{CONCLUSIONS}

The preservation of a dolomitization front of the limestone of the Meillon Formation in the Layens anticline is remarkable and grants access to a fossilized sequence displaying the expression of gradual degrees of dolomitization. The detailed investigation of crystallographic and chemical patterns at the interface between the original limestone and the dolomite allows assessment of the hydrothermal origin of the dolomitizing fluids in the Layens anticline. The first step of replacement is associated with $\mathrm{Zn}-\mathrm{Pb}$ rich dolomite precipitation in a reduced environment, along the grain boundaries, triggering the development of zebra-like patterns. Crystal-scale patterns of distribution of dolomite when the replacement is more advanced suggest that the crystal-scale propagation of dolomitization is controlled by diffusion-limited dissolution-precipitation process.

Mass balance calculations coupled to elementary transfer show that hydrothermal dolomitization involves a net mass loss of $c a 7 \mathrm{wt} \% \%$ for major element and $c a 40 \mathrm{wt} . \%$ of rare earth elements (REE) via aqueous fluid. This process is associated with the generation of porosity which compensates for the increase of density of dolomite crystals compared to calcite crystals. To account for the distribution patterns, it is proposed that this porosity generation is a key factor that allows the 
dissolution-precipitation to progress further in the crystal-scale as a self-enhanced mechanism, rather than using existing mineralogical defects. This study of a well-preserved natural case of dolomitization front is a further step in suggesting that the propagation of dolomitizing fluids and the related front may be tied to crystal-scale reactive transport mechanisms. The unravelling of transport mechanisms and crystal-scale pathways is an important step towards a more realistic comprehension of hydrothermal dolomitization at a larger scale.

\section{ACKNOWLEDGEMENTS}

This work is funded by the project TXM-R2 (Institut Carnot ISiFOR), S.C. and N.B. are funded through the isite-E2S, supported by the ANR PIA and the Région Nouvelle-Aquitaine. We thank Pascale Sénéchale for all the $\mu \mathrm{CT}$ scanning and volume reconstruction, Arnaud Proietti for the EBSD analyses and the help for the data processing. We thank Juan Diego Martín-Martín, three anonymous reviewers, and the Associate Editor Hairuo Qing for their interesting comments that improved the manuscript.

\section{DATA AVAILABILITY STATEMENT}

The data that support the findings of this study are openly available in the supplementary material of the present study. 


\section{REFERENCES}

Abele, G., Berger, K. and Salger, M. (1962) Die Uranvorkommen im Burgsandstein Mittelfrankens. Geol Bavarica, 49, 3-90.

Ague, J.J. (1991) Evidence for major mass transfer and volume strain during regional metamorphism of pelites. Geology, 19, 855-858.

Ague, J.J. (1994) Mass transfer during Barrovian metamorphism of pelites, South-Central Connecticut. I: Evidence for changes in composition and volume. American Journal of Science, 294, 989-1057.

Ague, J.J. (2017) Element mobility during regional metamorphism in crustal and subduction zone environments with a focus on the rare earth elements (REE). American Mineralogist, 102, 17961821.

Ague, J.J. and Nicolescu, S. (2014) Carbon dioxide released from subduction zones by fluidmediated reactions. Nature Geosci, 7, 355-360.

Aramendía, M., Rello, L., Bérail, S., Donnard, A., Pécheyran, C. and Resano, M. (2015) Direct analysis of dried blood spots by femtosecond-laser ablation-inductively coupled plasma-mass spectrometry. Feasibility of split-flow laser ablation for simultaneous trace element and isotopic analysis. J. Anal. At. Spectrom., 30, 296-309.

Beaudoin, N., Bellahsen, N., Lacombe, O., Emmanuel, L. and Pironon, J. (2014) Crustal-scale fluid flow during the tectonic evolution of the Bighorn Basin (Wyoming, USA). Basin Res, 26, 403-435.

Beaudoin, N., Hamilton, A., Koehn, D., Shipton, Z.K. and Kelka, U. (2018) Reaction-induced porosity fingering: Replacement dynamic and porosity evolution in the $\mathrm{KBr}-\mathrm{KCl}$ system. Geochimica et Cosmochimica Acta, 232, 163-180.

This article is protected by copyright. All rights reserved 
Breesch, L., Swennen, R., Vincent, B., Ellison, R. and Dewever, B. (2010) Dolomite cementation and recrystallisation of sedimentary breccias along the Musandam Platform margin (United Arab Emirates). Journal of Geochemical Exploration, 106, 34-43.

Centrella, S. (2019) The granulite- to eclogite- and amphibolite-facies transition: a volume and mass transfer study in the Lindås Nappe, Bergen Arcs, west Norway, Geological Society, London, Special Publications, From: FERRERO, S., LANARI, P., GONCALVES, P.\& GROSCH, E. G. (eds) Metamorphic Geology: Microscale to Mountain Belts 241-263.

Centrella, S., Austrheim, H. and Putnis, A. (2015) Coupled mass transfer through a fluid phase and volume preservation during the hydration of granulite: An example from the Bergen Arcs, Norway. Lithos, 236-237, 245-255.

Centrella, S., Austrheim, H. and Putnis, A. (2016) Mass transfer and trace element redistribution during hydration of granulites in the Bergen Arcs, Norway. Lithos, 262, 1-10.

Centrella, S., Putnis, A., Lanari, P. and Austrheim, H. (2018) Textural and chemical evolution of pyroxene during hydration and deformation: A consequence of retrograde metamorphism. Lithos, 296-299, 245-264.

Chen, Y., Chu, X.L., Zhang, X.L. and Zhai, M.G. (2015) Carbon isotopes, sulfur isotopes, and trace elements of the dolomites from the Dengying Formation in Zhenba area, southern Shaanxi: Implications for shallow water redox conditions during the terminal Ediacaran. Sci. China Earth Sci., 58, 1107-1122.

Chen, Y.-X., Schertl, H.-P., Zheng, Y.-F., Huang, F., Zhou, K. and Gong, Y.-Z. (2016) Mg-O isotopes trace the origin of $\mathrm{Mg}$-rich fluids in the deeply subducted continental crust of Western Alps. Earth and Planetary Science Letters, 456, 157-167.

Debure, M., Lassin, A., Marty, N.C., Claret, F., Virgone, A., Calassou, S. and Gaucher, E.C. (2019) Thermodynamic evidence of giant salt deposit formation by serpentinization: an alternative mechanism to solar evaporation. Scientific reports, 9, 11720.

This article is protected by copyright. All rights reserved 
Deininger, R.W. (1964) Ferrous iron and uranium concentrations and distributions in 100 selected limestones and dolomites. Dissertation, Rice University.

Diehl, S.F., Hofstra, A.H., Koenig, A.E., Emsbo, P., Christiansen, W. and Johnson, C. (2010) Hydrothermal zebra dolomite in the Great Basin, Nevada - Attributes and relation to Paleozoic stratigraphy, tectonics, and ore deposits. Geosphere, 6, 665-690.

Donard, A., Pointurier, F., Pottin, A.-C., Hubert, A. and Pécheyran, C. (2017) Determination of the isotopic composition of micrometric uranium particles by UV femtosecond laser ablation coupled with sector-field single-collector ICP-MS. J. Anal. At. Spectrom., 32, 96-106.

Eriksen, F.K., Toussaint, R., Måløy, K.J. and Flekkøy, E.G. (2015) Invasion patterns during twophase flow in deformable porous media. Front. Phys., 3, 312.

Feldkamp, L.A., Davis, L.C. and Kress, J.W. (1984) Practical cone-beam algorithm. Journal of Optical Society of America, 1, 612-619.

Gasparrini, M., Bechstädt, T. and Boni, M. (2006) Massive hydrothermal dolomites in the southwestern Cantabrian Zone (Spain) and their relation to the Late Variscan evolution. Marine and Petroleum Geology, 23, 543-568.

Golfier, F., Zarcone, C., Bazin, B., Lenormand, R., Lasseux, D. and Quintard, M. (2002) On the ability of a Darcy-scale model to capture wormhole formation during the dissolution of a porous medium. J. Fluid Mech., 457, 213-254.

Gomez-Rivas, E., Corbella, M., Martín-Martín, J.D., Stafford, S.L., Teixell, A., Bons, P.D., Griera, A. and Cardellach, E. (2014) Reactivity of dolomitizing fluids and Mg source evaluation of fault-controlled dolomitization at the Benicàssim outcrop analogue (Maestrat basin, E Spain). Marine and Petroleum Geology, 55, 26-42.

Graf, D.L. (1961) Crystallographic tables for the rhombohedral carbonates. American Mineralogist, 46, $1283-1316$.

Gresens, R.L. (1967) Composition-Volume relationships of metasomatism. Chemical Geology, 2, 47-65.

This article is protected by copyright. All rights reserved 
Haskin, L. and Gehl, M.A. (1962) The Rare-Earth distribution in sediments. Journal of Geophysical Research, 67, 2537-2541.

Henderson, P. (1984) Chapter 1 - General Geochemical Properties and Abundances of the Rare Earth Elements. In: Rare Earth Element Geochemistry (Ed. P. Henderson), Developments in Geochemistry, 2, pp. 1-32. Elsevier.

Hermann, J., Zheng, Y.-F. and Rubatto, D. (2013) Deep Fluids in Subducted Continental Crust. Elements, 9, 281-287.

Huang, J., Chu, X., Jiang, G., Feng, L. and Chang, H. (2011) Hydrothermal origin of elevated iron, manganese and redox-sensitive trace elements in the c . 635 Ma Doushantuo cap carbonate. Journal of the Geological Society, 168, 805-816.

Incerpi, N., Manatschal, G., Martire, L., Bernasconi, S.M., Gerdes, A. and Bertok, C. (2020) Characteristics and timing of hydrothermal fluid circulation in the fossil Pyrenean hyperextended rift system: new constraints from the Chaînons Béarnais (W Pyrenees). Int J Earth Sci (Geol Rundsch), 110, 1.

Izquierdo-Llavall, E., Menant, A., Aubourg, C., Callot, J.-P., Hoareau, G., Lahfid, A., Camps, P. and Pere, E. (2020) Pre-orogenic folds and syn-orogenic basement tilts in an inverted hyperextended margin : the northern Pyrenees case study. Tectonics, 39.

James, V. (1998), La plate-forme carbonatée ouest-pyrénéenne au Jurassique moyen et supérieur. $\mathrm{PhD}$, Toulouse, $355 \mathrm{pp}$.

Jamtveit, B., Austrheim, H. and Malthe-Sørenssen, A. (2000) Accelerated hydration of the Earth's deep crust induced by stress perturbations. Nature, 408, 75-78.

Jamtveit, B. and Hammer, Ø. (2012) Sculpting of Rocks by Reactive Fluids. Geochem Persp, 1, $341-481$.

Jamtveit, B., Malthe-Sørenssen, A. and Kostenko, O. (2008) Reaction enhanced permeability during retrogressive metamorphism. Earth and Planetary Science Letters, 267, 620-627. 
Jochum, K.P., Weis, U., Stoll, B., Kuzmin, D., Yang, Q., Raczek, I., Jacob, D.E., Stracke, A., Birbaum, K., Frick, D.A., Günther, D. and Enzweiler, J. (2011) Determination of Reference Values for NIST SRM 610-617 Glasses Following ISO Guidelines. Geostandards and Geoanalytical Research, 35, 397-429.

Jochum, K.P., Wilson, S.A., Abouchami, W., Amini, M., Chmeleff, J., Eisenhauer, A., Hegner, E., Iaccheri, L.M., Kieffer, B., Krause, J., McDonough, W.F., Mertz-Kraus, R., Raczek, I., Rudnick, R.L., Scholz, D., Steinhoefel, G., Stoll, B., Stracke, A., Tonarini, S., Weis, D., Weis, U. and Woodhead, J.D. (2010) GSD-1G and MPI-DING Reference Glasses for In Situ and Bulk Isotopic Determination. Geostandards and Geoanalytical Research, 35, 193-226.

Jonas, L., Müller, T., Dohmen, R., Baumgartner, L. and Putlitz, B. (2015) Transport-controlled hydrothermal replacement of calcite by Mg-carbonates. Geology, 43, 779-782.

Jonas, L., Müller, T., Dohmen, R., Immenhauser, A. and Putlitz, B. (2017) Hydrothermal replacement of biogenic and abiogenic aragonite by Mg-carbonates - Relation between textural control on effective element fluxes and resulting carbonate phase. Geochimica et Cosmochimica Acta, 196, 289-306.

Kar, A., Chiang, T.-Y., Ortiz Rivera, I., Sen, A. and Velegol, D. (2015) Enhanced transport into and out of dead-end pores. ACS nano, 9, 746-753.

Kelemen, P.B. and Hirth, G. (2012) Reaction-driven cracking during retrograde metamorphism: Olivine hydration and carbonation. Earth and Planetary Science Letters, 345-348, 81-89.

Kelka, U. (2017) Pattern Formation in Mississippi Valley-Type Deposits - Identifying one of Nature's Fundamental Processes in Geologic Systems. PhD thesis. School of Geographical and Earth Sciences, College of Science and Engineering, University of Glasgow, 355.

Kelka, U., Koehn, D. and Beaudoin, N. (2015) Zebra pattern in rocks as a function of grain growth affected by second-phase particles. Front. Phys., 3, 201.

Kelka, U., Veveakis, M., Koehn, D. and Beaudoin, N. (2017) Zebra rocks: compaction waves create ore deposits. Scientific reports, 7, 14260.

This article is protected by copyright. All rights reserved 
Kirschner, J.P. and Barnes, D.A. (2009) Geological sequestration capacity of the Dundee Limestone, Michigan Basin, United States. Environ. Geosci., 16, 127-138.

Koeshidayatullah, A., Corlett, H., Stacey, J., Swart, P.K., Boyce, A. and Hollis, C. (2020b) Origin and evolution of fault-controlled hydrothermal dolomitization fronts: A new insight. Earth and Planetary Science Letters, 541, 116291.

Koeshidayatullah, A., Corlett, H., Stacey, J., Swart, P.K., Boyce, A., Robertson, H., Whitaker, F. and Hollis, C. (2020a) Evaluating new fault-controlled hydrothermal dolomitization models: Insights from the Cambrian Dolomite, Western Canadian Sedimentary Basin. Sedimentology, 26, 515.

Kondratiuk, P., Tredak, H., Ladd, A.J.C. and Szymczak, P. (2015) Synchronization of dissolution and precipitation fronts during infiltration-driven replacement in porous rocks. Geophys. Res. Lett., 42, 2244-2252.

Krug, H.-J., Brandtstädter, H. and Jacob, K.H. (1996) Morphological instabilities in pattern formation by precipitation and crystallization processes. Geol Rundsch, 85, 19-28.

Labaume, P. and Teixell, A. (2020) Evolution of salt structures of the Pyrenean rift (Chaînons Béarnais, France): From hyper-extension to tectonic inversion. Tectonophysics, 785.

Lagabrielle, Y., Labaume, P. and Saint Blanquat, M.d. (2010) Mantle exhumation, crustal denudation, and gravity tectonics during Cretaceous rifting in the Pyrenean realm (SW Europe): Insights from the geological setting of the lherzolite bodies. Tectonics, 29, n/a-n/a.

Lanari, P., Vho, A., Bovay, T., Airaghi, L. and Centrella, S. (2019) Quantitative compositional mapping of mineral phases by electron probe micro-analyser. Geological Society, London, Special Publications, From: FERRERO, S., LANARI, P., GONCALVES, P.\& GROSCH, E. G. (eds) Metamorphic Geology: Microscale to Mountain Belts, 478, 39-63.

Lanari, P., Vidal, O., Andrade, V.d., Dubacq, B., Lewin, E., Grosch, E.G. and Schwartz, S. (2014) XMapTools: A MATLABC-based program for electron microprobe X-ray image processing and geothermobarometry. Computers \& Geosciences, 62, 227-240.

This article is protected by copyright. All rights reserved 
Leach, D.L. and Viets, J.G. (1992) Comparison of the Cracow-Silesian Mississippi valley-type district, southern Poland, with Mississippi valley-type districts in North America. Open-File Report.

Lenoble, J.-L. (1992), Les plates-formes carbonatées ouest pyrénéennes du Dogger à l'Albien. PhD, Toulouse, $447 \mathrm{pp}$.

Ling, H.-F., Chen, X., Li, D., Wang, D., Shields-Zhou, G.A. and Zhu, M. (2013) Cerium anomaly variations in Ediacaran-earliest Cambrian carbonates from the Yangtze Gorges area, South China: Implications for oxygenation of coeval shallow seawater. Precambrian Research, 225, $110-127$.

Machel, H.G. (2004) Concepts and models of dolomitization: a critical reappraisal. Geological Society, London, Special Publications, From: BRAITHWAITE, C. J. R., RIZZ1, G. \& DARKE, G. (eds) 2004. The Geometry and Petrogenesis of Dolomite Hydrocarbon Reservoirs. Geological Society, London, Special Publications, 235, 7-63.

Machel, H.G. and Lonnee, J. (2002) Hydrothermal dolomite—a product of poor definition and imagination. Sedimentary Geology, 152, 163-171.

Machel, H.G. and Mountjoy, E.W. (1986) Chemistry and Environments of Dolomitization - A Reappraisal. Earth Science Reviews, 23, 175-222.

Martín-Martín, J.D., Travé, A., Gomez-Rivas, E., Salas, R., Sizun, J.-P., Vergés, J., Corbella, M., Stafford, S.L. and Alfonso, P. (2015) Fault-controlled and stratabound dolostones in the Late Aptian-earliest Albian Benassal Formation (Maestrat Basin, E Spain): Petrology and geochemistry constrains. Marine and Petroleum Geology, 65, 83-102.

Masini, E., Manatschal, G., Tugend, J., Mohn, G. and Flament, J.-M. (2014) The tectonosedimentary evolution of a hyper-extended rift basin: the example of the Arzacq-Mauléon rift system (Western Pyrenees, SW France). Int J Earth Sci (Geol Rundsch), 103, 1569-1596.

This article is protected by copyright. All rights reserved 
Merino, E. and Canals, A. (2011) Self-accelerating dolomite for calcite replacement: self organized dynamics of burial dolomitization and associated mineralization. American Journal of Science, 311, 573-607.

Montes-Hernandez, G., Renard, F., Auzende, A.-L. and Findling, N. (2020) Amorphous CalciumMagnesium Carbonate (ACMC) Accelerates Dolomitization at Room Temperature under Abiotic Conditions. Crystal Growth \& Design, 20, 1434-1441.

\section{Mouthereau, F., Filleaudeau, P.-Y., Vacherat, A., Pik, R., Lacombe, O., Fellin, M.G.,} Castelltort, S., Christophoul, F. and Masini, E. (2014) Placing limits to shortening evolution in the Pyrenees: Role of margin architecture and implications for the Iberia/Europe convergence. Tectonics, 33, 2283-2314.

Mozafari, M., Swennen, R., Balsamo, F., El Desouky, H., Storti, F. and Taberner, C. (2019) Fault-controlled dolomitization in the Montagna dei Fiori Anticline (Central Apennines, Italy): record of a dominantly pre-orogenic fluid migration. Solid Earth, 10, 1355-1383.

Nader, F.H., López-Horgue, M.A., Shah, M.M., Dewit, J., Garcia, D., Swennen, R., Iriarte, E., Muchez, P. and Caline, B. (2012) The Ranero Hydrothermal Dolomites (Albian, Karrantza Valley, Northwest Spain): Implications on Conceptual Dolomite Models. Oil Gas Sci. Technol. Rev. IFP Energies nouvelles, 67, 9-29.

Palinkaš, S.S., Spangenberg, J.E. and Palinkaš, L.A. (2009) Organic and inorganic geochemistry of Ljubija siderite deposits, NW Bosnia and Herzegovina. Miner Deposita, 44, 893-913.

Paradis, S., Hannigan, P. and Dewing, K. (2007) Mississippi Valley-type lead-zinc deposits (MVT). in Goodfellow, W.D., ed., Mineral Deposits of Canada: A Synthesis of Major Deposit-Types, District Metallogeny, the Evolution of Geological Provinces, and Exploration Methods: Geological Association of Canada, Mineral Deposits Division, Special Publication, 5, 185-203.

Paton, C., Hellstrom, J., Paul, B., Woodhead, J. and Hergt, J. (2011) Iolite: Freeware for the visualisation and processing of mass spectrometric data. J. Anal. At. Spectrom., 26, 2508. 
Pearce, M.A., Timms, N.E., Hough, R.M. and Cleverley, J.S. (2013) Reaction mechanism for the replacement of calcite by dolomite and siderite: implications for geochemistry, microstructure and porosity evolution during hydrothermal mineralisation. Contrib Mineral Petrol, 166, 995-1009.

Pedrosa, E.T., Putnis, C.V. and Putnis, A. (2016a) The pseudomorphic replacement of marble by apatite: The role of fluid composition. Chemical Geology, 425, 1-11.

Pedrosa, E.T., Putnis, C.V., Renard, F., Burgos-Cara, A., Laurich, B. and Putnis, A. (2016b) Porosity generated during the fluid-mediated replacement of calcite by fluorite. CrystEngComm, 18, 6867-6874.

Peters, D. and Pettke, T. (2017) Evaluation of Major to Ultra Trace Element Bulk Rock Chemical Analysis of Nanoparticulate Pressed Powder Pellets by LA-ICP-MS. Geostand Geoanal Res, 41, $5-28$.

Pinto, V.H.G., Manatschal, G., Karpoff, A.M., Ulrich, M. and Viana, A.R. (2017) Seawater storage and element transfer associated with mantle serpentinization in magma-poor rifted margins: A quantitative approach. Earth and Planetary Science Letters, 459, 227-237.

Piper, D.Z. (1974) Rare Earth Elements in the Sedimentary Cycle: A Summary. Chemical Geology, 14, 285-304.

Puigdefàbregas and Souquet (1986) Tecto-sedimentary cycles and depositional sequences of Mesozoic and Tertiary from the Pyrenees. Tectonophysics, 129, 173-203.

Putnis, A. (2002) Mineral replacement reactions: from macroscopic observations to microscopic mechanisms. Mineral. mag., 66, 689-708.

Putnis, A. (2009) Mineral Replacement Reactions. Reviews in Mineralogy and Geochemistry, 70, 87124.

Putnis, A. and Putnis, C.V . (2007) The mechanism of reequilibration of solids in the presence of a fluid phase. Journal of Solid State Chemistry, 180, 1783-1786.

Putnis, C.V. and Mezger, K. (2004) A mechanism of mineral replacement: isotope tracing in the model system KCl-KBr-H2O. Geochimica et Cosmochimica Acta, 68, 2839-2848.

This article is protected by copyright. All rights reserved 
Putnis, C.V., Tsukamoto, K. and Nishimura, Y. (2005) Direct observations of pseudomorphism: compositional and textural evolution at a fluid-solid interface. American Mineralogist, 90, 19091912.

Quesnel, B., Boiron, M.C., Cathelineau, M., Truche, L., Rigaudier, T., Bardoux, G., Agrinier, P., Saint Blanquat, M.d., Masini, E. and Gaucher, E.C. (2019) Nature and Origin of Mineralizing Fluids in Hyperextensional Systems: The Case of Cretaceous Mg Metasomatism in the Pyrenees. Geofluids, 2019, 1-18.

Ramachandran, G.N. and Lakshminarayanan, A.V. (1971) Three-dimensional Reconstruction from Radiographs and Electron Micrographs Application of Convolutions instead of Fourier Transforms. Proceedings of the National Academy of Sciences of the United States of America, 68, 2236-2240.

Raufaste, C., Jamtveit, B., John, T., Paul, M. and Dysthe, D. (2011) The mechanism of porosity formation during solvent-mediated phase transformations. Proceedings of the Royal Society A, 467, 1408-1426.

Ruiz-Agudo, E., Putnis, C.V. and Putnis, A. (2014) Coupled dissolution and precipitation at mineral-fluid interfaces. Chemical Geology, 383, 132-146.

Salardon, R., Carpentier, C., Bellahsen, N., Pironon, J. and France-Lanord, C. (2017) Interactions between tectonics and fluid circulations in an inverted hyper-extended basin: Example of Mesozoic carbonate rocks of the western North Pyrenean Zone (Chaînons Béarnais, France). Marine and Petroleum Geology, 80, 563-586.

Scribano, V., Carbone, S., Manuella, F.C., Hovland, M., Rueslåtten, H. and Johnsen, H.-K. (2017) Origin of salt giants in abyssal serpentinite systems. Int J Earth Sci (Geol Rundsch), 106, 2595-2608.

Slaughter, M. and Hill, R.J. (1991) The Influence of Organic Matter in Organogenic Dolomitization: PERSPECTIVE. Journal of Sedimentary Petrology, 61, 296-303.

This article is protected by copyright. All rights reserved 
Steinfink, H. and Sans, F.J. (1959) Refinement of the crystal structure of dolomite. American Mineralogist, 44, 679-682.

Swennen, R., Dewit, J., Fierens, E.L.S., Muchez, P., Shah, M., Nader, F. and Hunt, D. (2012) Multiple dolomitization events along the Pozalagua Fault (Pozalagua Quarry, Basque-Cantabrian Basin, Northern Spain). Sedimentology, 59, 1345-1374.

Szymczak, P. and Ladd, A.J.C. (2006) A network model of channel competition in fracture dissolution. Geophys. Res. Lett., 33, 45.

Szymczak, P. and Ladd, A.J.C. (2014) Reactive-infiltration instabilities in rocks. Part 2. Dissolution of a porous matrix. J. Fluid Mech., 738, 591-630.

Teixell, A., Labaume, P. and Lagabrielle, Y. (2016) The crustal evolution of the west-central Pyrenees revisited: Inferences from a new kinematic scenario. Comptes Rendus Geoscience, 348, $257-267$.

Thibeau, S., Chiquet, P., Prinet, C. and Lescanne, M. (2013) Lacq-Rousse CO2 Capture and Storage Demonstration Pilot: Lessons Learnt from Reservoir Modelling Studies. Energy Procedia, 37, 6306-6316.

Tugend, J., Manatschal, G. and Kusznir, N.J. (2015) Spatial and temporal evolution of hyperextended rift systems: Implication for the nature, kinematics, and timing of the IberianEuropean plate boundary. Geology, 43, 15-18.

Vacherat, A., Mouthereau, F., Pik, R., Bernet, M., Gautheron, C., Masini, E., Le Pourhiet, L., Tibari, B. and Lahfid, A. (2014) Thermal imprint of rift-related processes in orogens as recorded in the Pyrenees. Earth and Planetary Science Letters, 408, 296-306.

Wallace, M.W., Both, R.A., Ruano, S.M., Fenoll Hach-Ali, P. and Lees, T. (1994) Zebra textures from carbonate-hosted sulfide deposits; sheet cavity networks produced by fracture and solution enlargement. Economic Geology, 89, 1183-1191.

Warren, J. (2000) Dolomite: occurrence, evolution and economically important associations. Earth Science Reviews, 52, 1-81. 
Welte, D.H. (1962) Sedimentologische Untersuchung uranhaltiger Keupersedimente aus der Umgebung von Lichtenfels bei Coburg. Geol Bavarica, 49, 91-123.

Wheeler, J. (1987) The significance of grain-scale stresses in the kinetics of metamorphism. Contributions to Mineralogy and Petrology, 97, 397-404.

Whitaker, F.F., Smart, P.L. and Jones, G.D. (2004) Dolomitization: from conceptual to numerical models. From: BRAITHWAITE, C. J. R., Rizzi, G. \& DARKE, G. (eds) 2004. The Geometry and Petrogenesis of Dolomite Hydrocarbon Reservoirs. Geological Society, London, Special Publications, 235, 99-139.

White, W. (2013), Geochemistry, 55 pp.

Wilson, E.N., Hardie, L.A. and Phillips, O.M. (1990) Dolomitization front geometry, fluid flow patterns, and the origin of massive dolomite the Triassic Latemar buildup northern Italy. American Journal of Science, 290, 741-796.

Xu, L., Marks, B., Toussaint, R., Flekkøy, E.G. and Måløy, K.J. (2018) Dispersion in Fractures With Ramified Dissolution Patterns. Front. Phys., 6, 186.

Zhang, W., Guan, P., Jian, X., Feng, F. and Zou, C. (2014) In situ geochemistry of Lower Paleozoic dolomites in the northwestern Tarim basin: Implications for the nature, origin, and evolution of diagenetic fluids. Geochem. Geophys. Geosyst., 15, 2744-2764.

Zhou, C.M., Jiang, S.Y., Xiao, S.H., Chen, Z. and Yuan, X.L. (2012) Rare earth elements and carbon isotope geochemistry of the Doushantuo Formation in South China: Implication for middle Ediacaran shallow marine redox conditions. Chin. Sci. Bull., 57, 1998-2006

This article is protected by copyright. All rights reserved 


\section{FIGURE CAPTIONS}

Fig. 1. (A) Structural map of the Pyrenees. NPFT: North Pyrenean Frontal Thrust, NPF: North Pyrenean Fault, SPF: South Pyrenean Fault, SPFT: South Pyrenean Frontal Thrust, NPZ and SPZ: North and South Pyrenean Zone, HP LT: High pressure low temperature (after Vauchez et al., 2013). (B) Structural map of the Chaînons Béarnais region, with location of the panoramic view shown in Fig. 2 and of the map in Fig. 3 (rectangle) (modified after Casteras, 1970; Lagabrielle et al., 2010; Corre \& Lagabrielle, 2015). Location of the outcrop in this study shown by a yellow star (4301'11.9’N, O॰39’15.3”W).

Fig. 2 (A) and (B) Photograph of the Callovian-Oxfordian limestone of the Meillon Formation cropping out in the Layens anticline. (C) High-resolution two-dimensional scan of a polished slab of studied calcite-dolomite interface. (D) Photograph of a coated thin section from across the hand specimen with location of lighter stripes (black arrows).

Fig. 3. (A) X-ray microtomography $(\mu \mathrm{CT})$ slice from the area of scan 3 with its phase segmentation based on the grey value of each voxel (which depends on its atomic number and density). (B) Threedimensional volumes extracted from X-ray microtomography scan of scan 3 as located in Fig. 2. Each block represents one of the four constitutive phases of the rock.

Fig. 4. Scanning electron microscopy (SEM) backscattered images of the sample showing: (A) the general aspect of the original calcite; $(\mathbf{B})$ calcite in reaction zone; $(\mathbf{C})$ and $(\mathbf{D})$ dolomite.

Fig. 5. (A) Backscattered electron (BSE) image of the calcite-dolomite transition. Dolomite (B) and calcite $(\mathbf{C})$ grain size overlain in semi-transparency with band contrast (circle equivalent diameter in $\mu \mathrm{m})$. Band contrast represents the electron backscatter pattern quality, the brighter the value, the 
better the diffraction quality. Volume percent profile of calcite-dolomite (D) and porosity-oxide (E) segmented from the X-ray CT scan calculated in subvolumes of around $1 \mathrm{~mm}^{3}$. X-axis represents the length and position of each core. Scan location is shown in Fig. 2C.

Fig. 6. (A) Three-dimensional volume in reaction zone A of the coarse calcite showing the replacement of calcite (light transparent white) by dolomite (black) and porosity (red). (B) 3D volume in reaction zone B of the coarse calcite showing the replacement of calcite (light grey) by dolomite (black). Note the small scale infiltration of dolomite in the calcite patches in (C).

Fig. 7. Spider diagram for individual phases normalized to world shale (Piper, 1974). Each area represents all of the measurements at 2 se (standard error). The large range of values at 2 se is due to a small grain size associated with porosity and oxides present at grain boundaries.

Fig. 8. Sample located in the calcite-dolomite transition (scan 2). Phase map (A) with associated Zn (B) and $\mathrm{Pb}(\mathbf{C})$. Maps were calibrated using $\mathrm{Ca}$ in calcite, the absolute concentration values are only valid for the pixels of calcite. Using $\mathrm{Mg}$ in dolomite as internal standard, the concentration of the mixed phase changes about one order of magnitude becoming closer to the dolomite concentration. Note that the colour scale is logarithmic. Pixel size 20 x $20 \mu \mathrm{m}$.

Fig. 9. (A) The overall gains and losses of elements from the replacement of calcite in a reaction zone by dolomite is plotted as a function of the volume change during the reaction. See text for details. For clarity, $\mathrm{MnO}$ and $\mathrm{FeO}$ are not shown. (B) Sum of gains and losses of elements as a function of the volume change during the reaction. (C) Profile of mass change (\%) across the reaction zone taking into account the proportion of dolomite and calcite derived from X-ray $\mu \mathrm{CT}$ (Fig. 4C). These proportion are coupled to the mass balance equation where the fully replaced calcite formed $93.13 \mathrm{~g}$ of dolomite (100 vol.\%) and correspond to $c a 7 \%$ of mass loss and a $\Delta \mathrm{V}=-11 \%$.

This article is protected by copyright. All rights reserved 
Fig. 10. Overall gains and losses of rare earth elements (REEs) (A), high field strength elements and large ion lithophile elements (HFSE - LILE) (B) during dolomitization with 11\% of volume loss. Error bars represent the 2 se (standard error). For greater visibility, gain in mass is fixed at 100\% (A) and $150 \%$ (B). Aluminium, $\mathrm{V}$ and $\mathrm{U}$ gained $+207 \%,+259 \%$ and $+693 \%$ of mass, respectively. Since these elements are present in low concentrations in calcite, a small variation in concentration results in a large variation in mass.

Fig. 11. Schematic sketch illustrating the entire replacement of calcite by dolomite. (A) Recrystallization of the original calcite into a coarse grained calcite. (B) Fluid infiltration (blue arrows) through grain boundaries and dolomite precipitation. Fluid infiltrates some crystals and generates porosity. Element exchange between the fluid, calcite and dolomite is constant and shown in the lower right corner of the figure. (C) Fluid/dolomite continues to infiltrate the crystal and starts to isolate some calcite crystals. Replacement continues with isolated calcite crystals (D) still present until being fully replaced $(\mathbf{E})$. Black dots represent the porosity and black arrows the diffusion limited replacement.

Fig. S1. Outcrop showing the contact between the original limestone and the dolomite.

Fig. S2. Pole figures lower hemispheres showing that none of the phases shows any crystal preferred orientation. All hemispheres have a half width $10^{\circ}$ and a cluster size $5^{\circ}$.

Fig. S3. Box plot of the respective volume of the porosity and grain size area for dolomite and calcite $\left(\mu \mathrm{m}^{2}\right)$ across the hand specimen.

This article is protected by copyright. All rights reserved 
Table S1. Microprobe analyses of calcite and dolomite (wt.\%). Structural formula has been calculated normalized to two oxygens.

Table S2. Results of trace elements content by LA-ICP-MS (ppm) and 2 se (two standard error). 


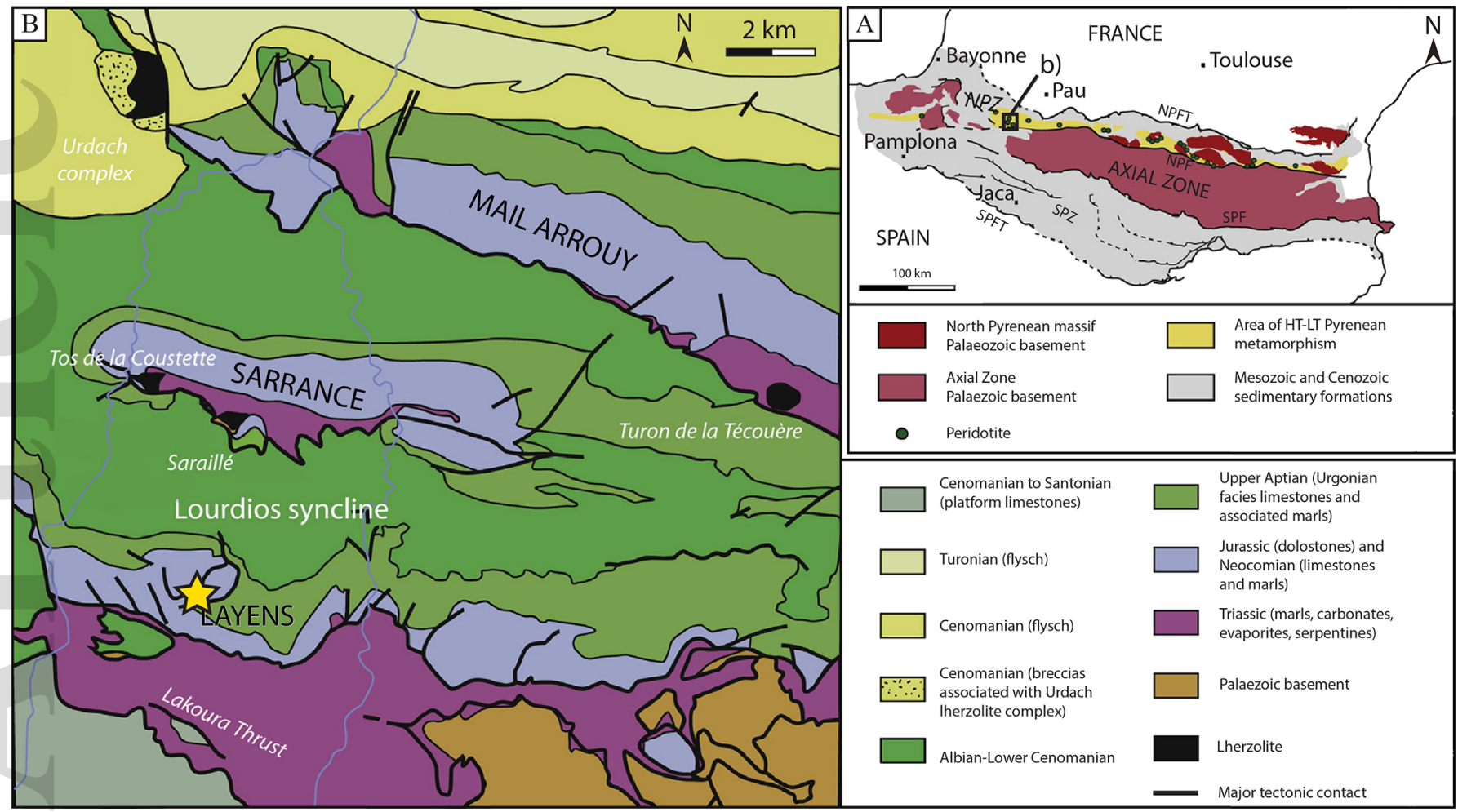

sed_12808_f1.tif 

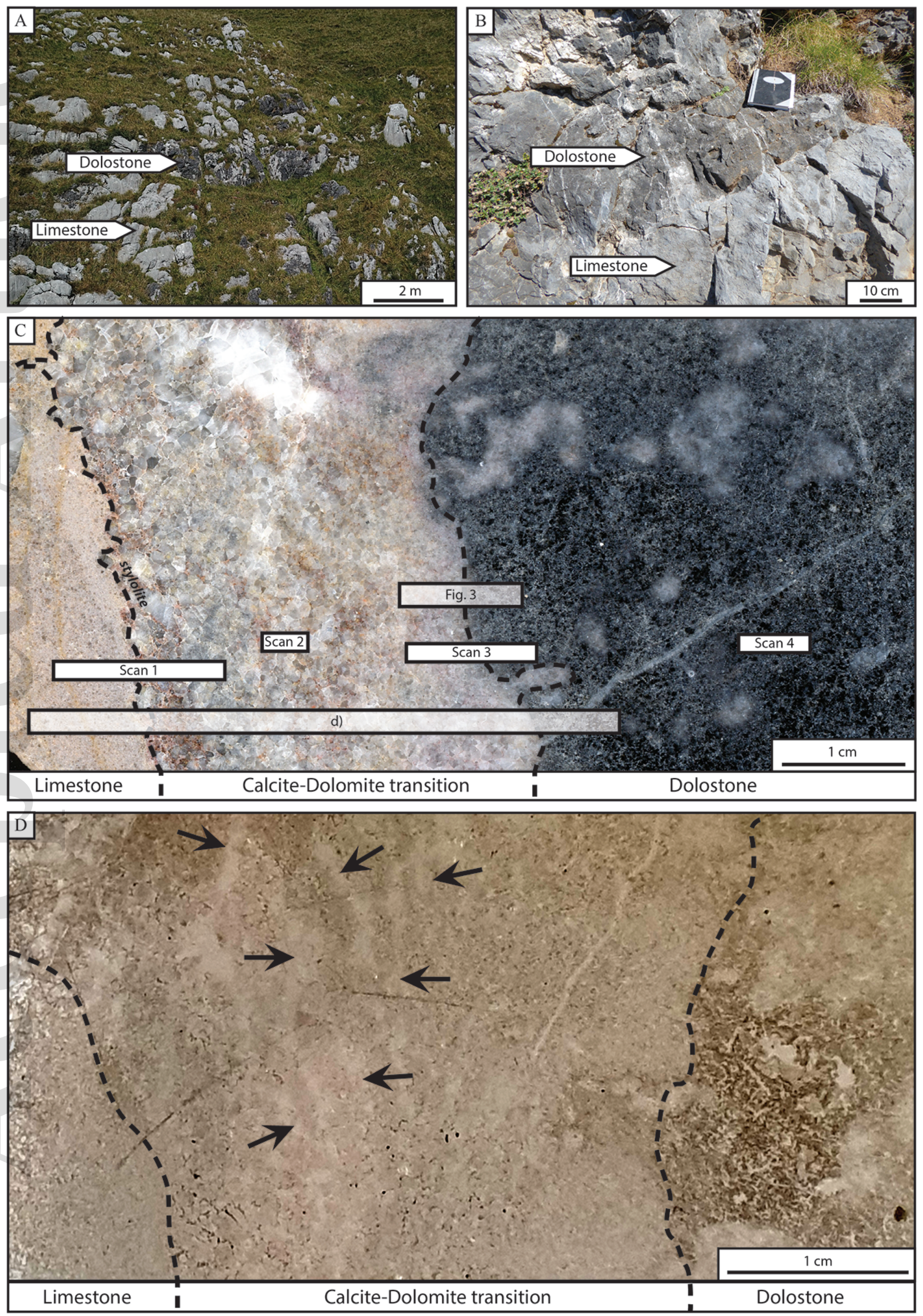

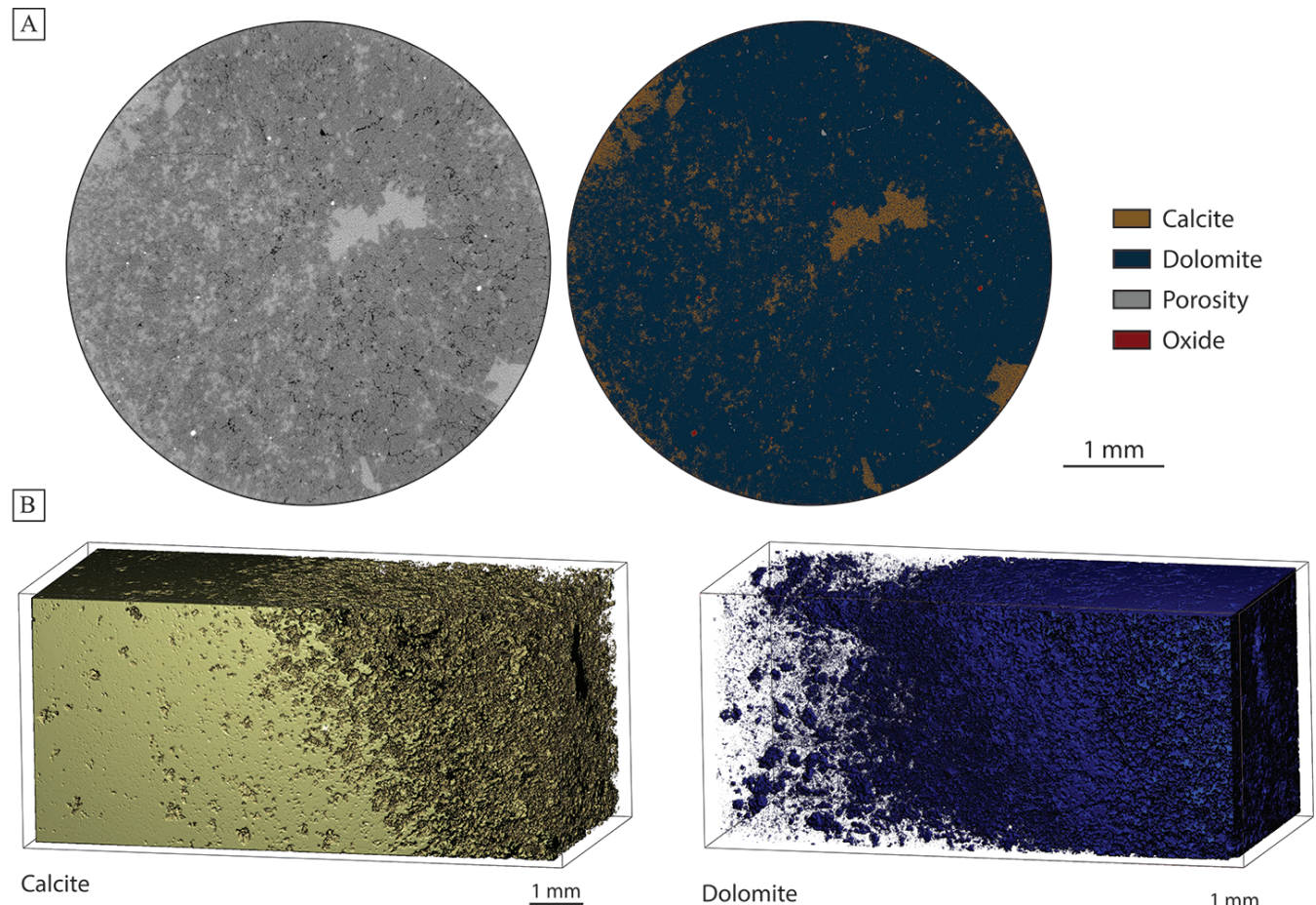

Calcite

Dolomite

$1 \mathrm{~mm}$
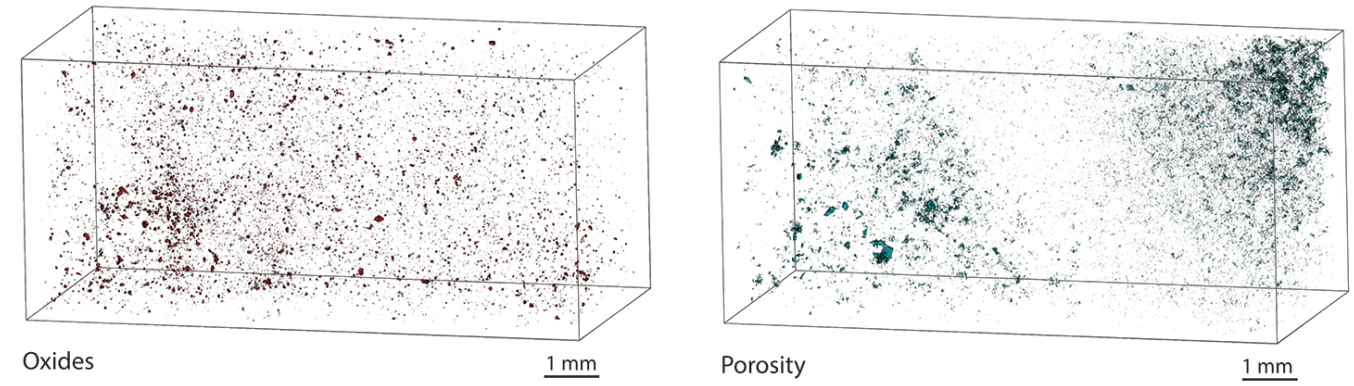

sed_12808_f3.tif 

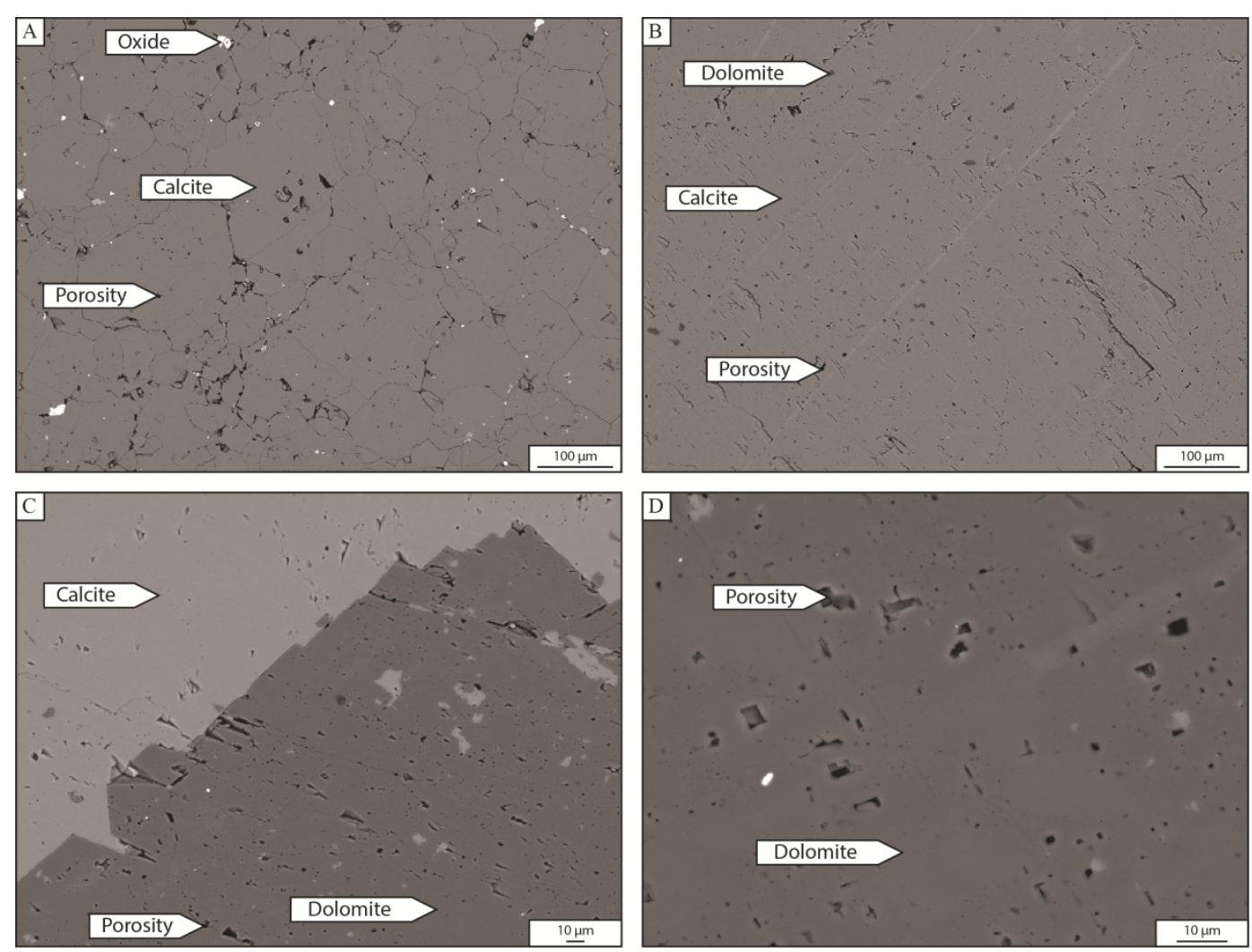

sed_12808_f4.tif 

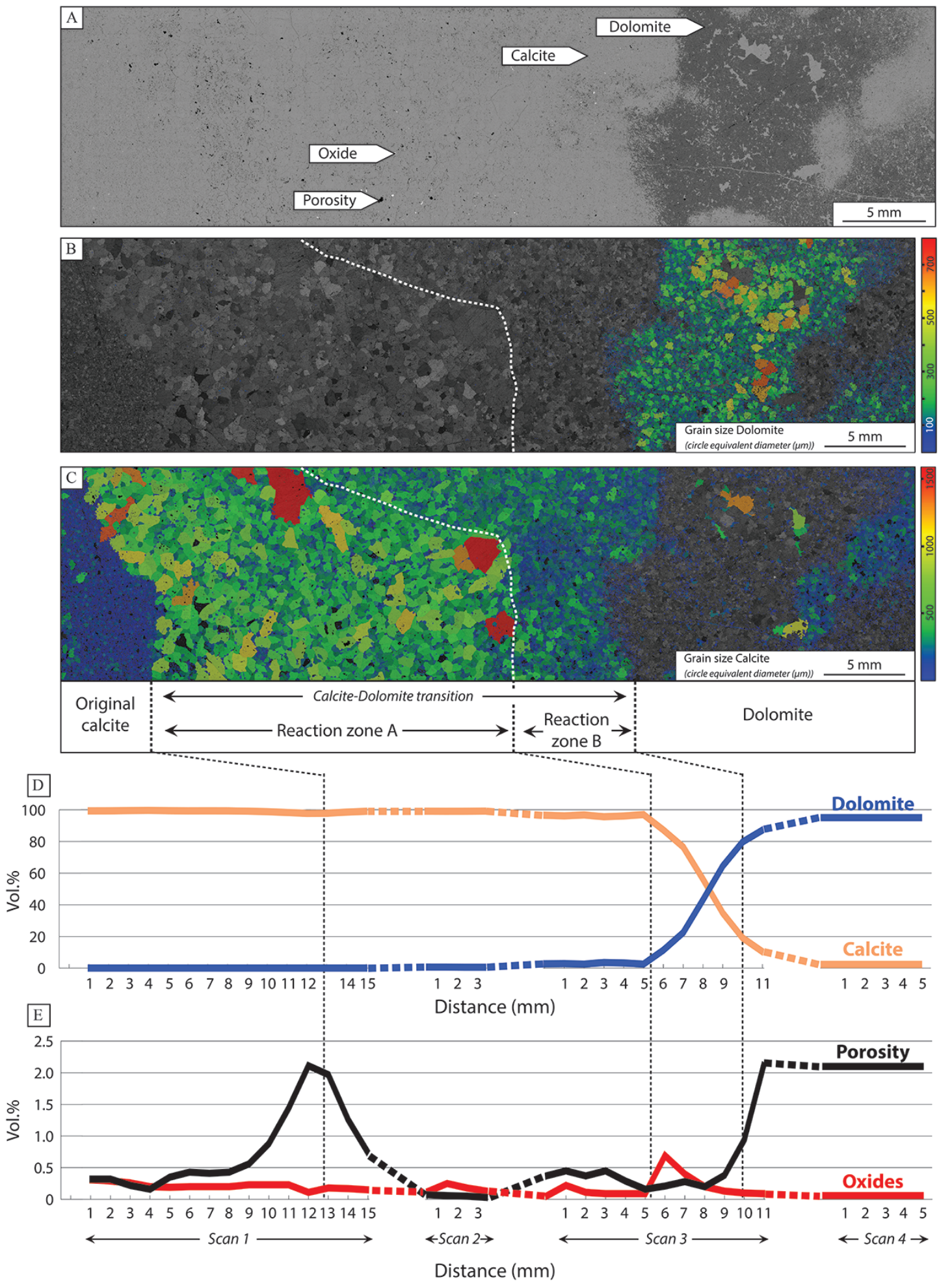

sed_12808_f5.tif 

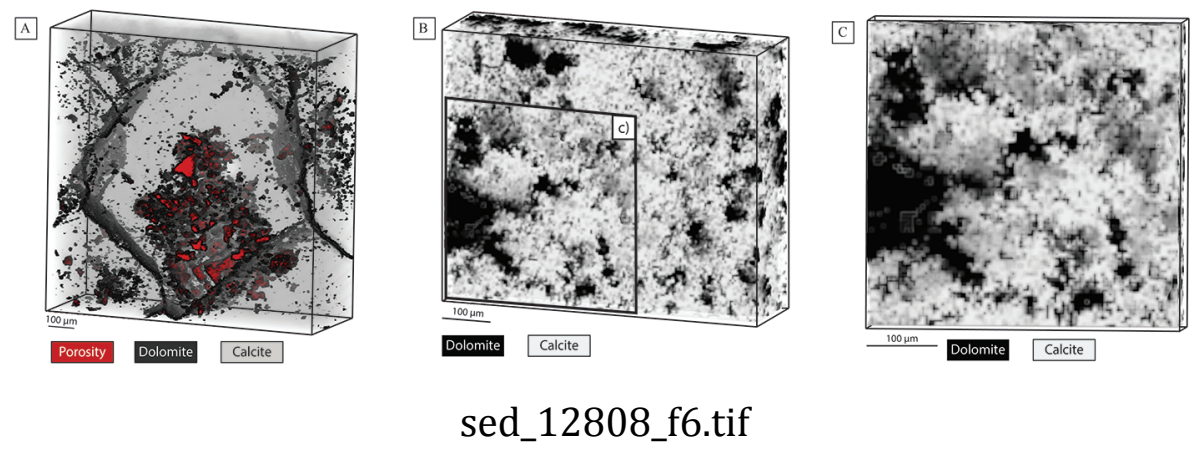

This article is protected by copyright. All rights reserved 


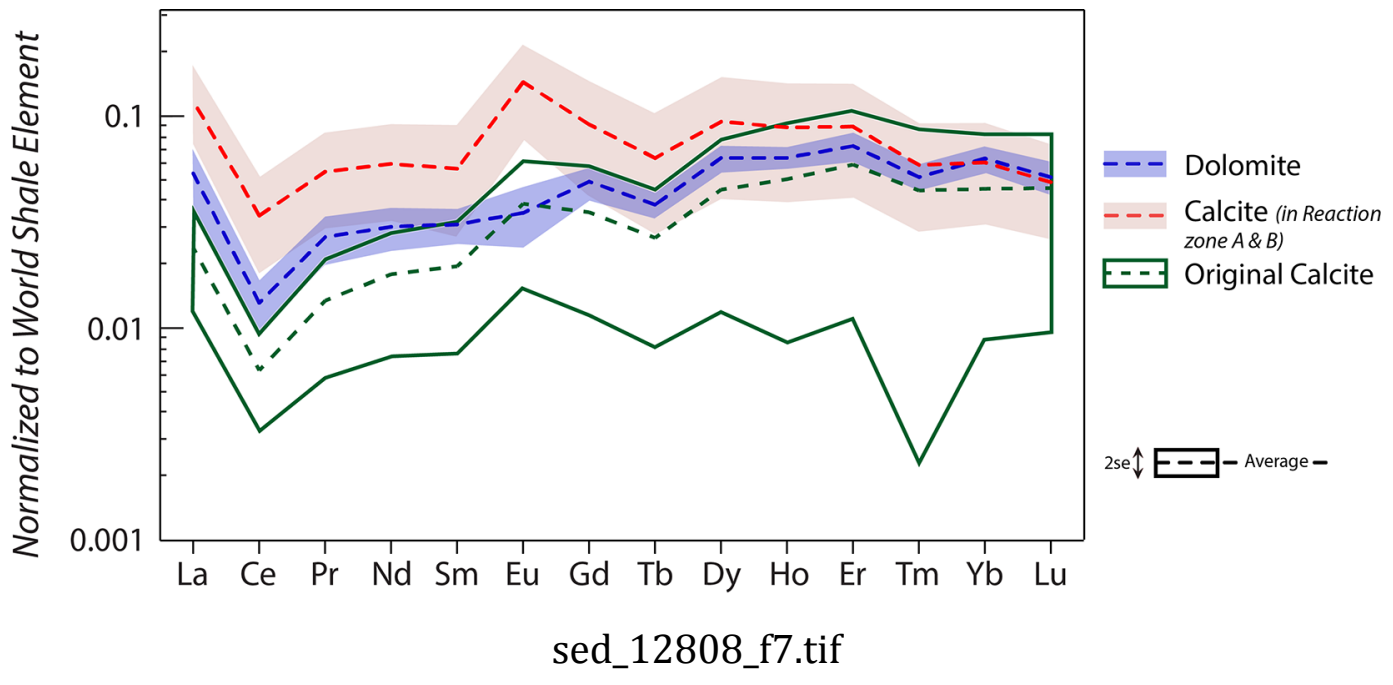

This article is protected by copyright. All rights reserved 

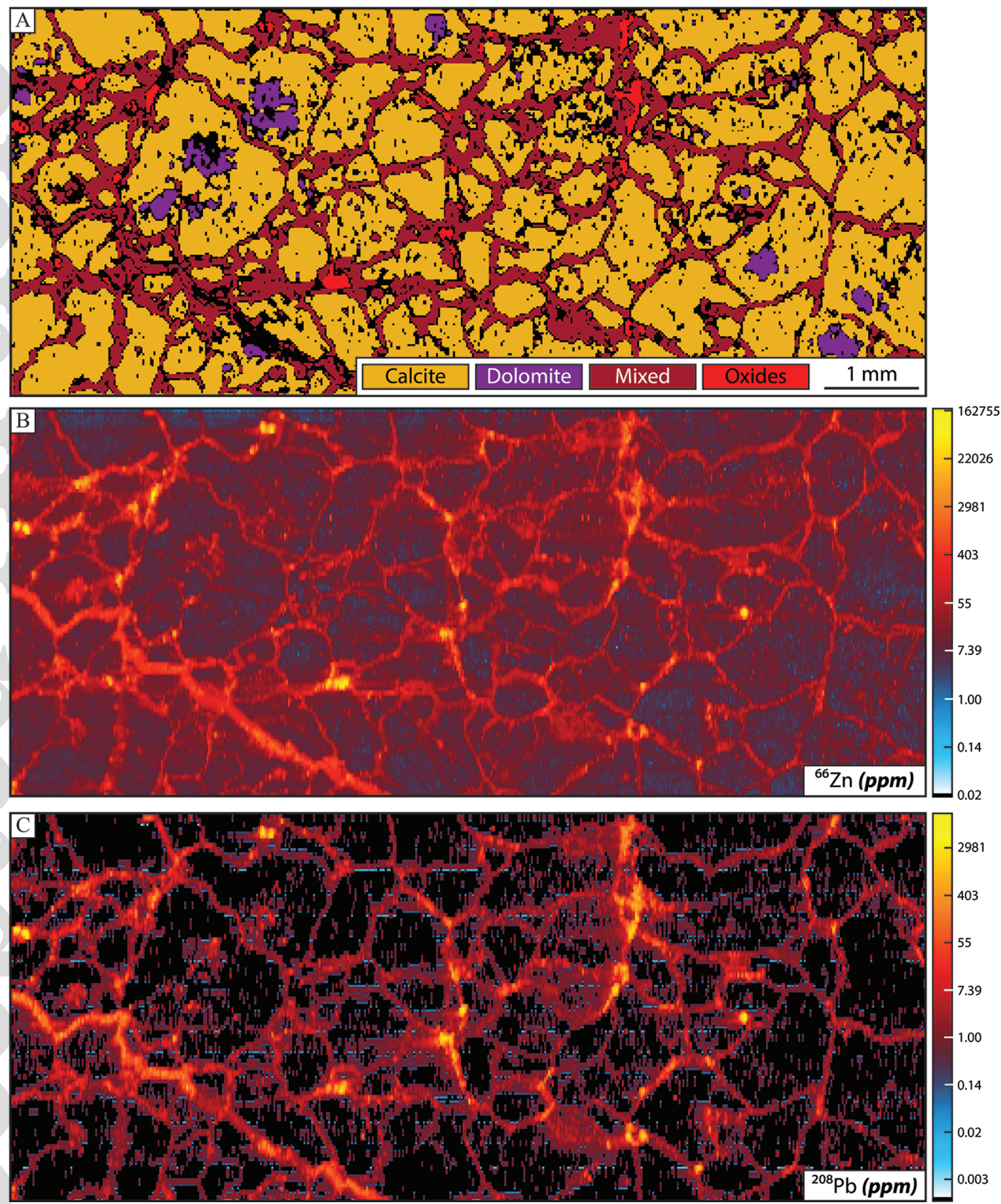

sed_12808_f8.tif

This article is protected by copyright. All rights reserved 

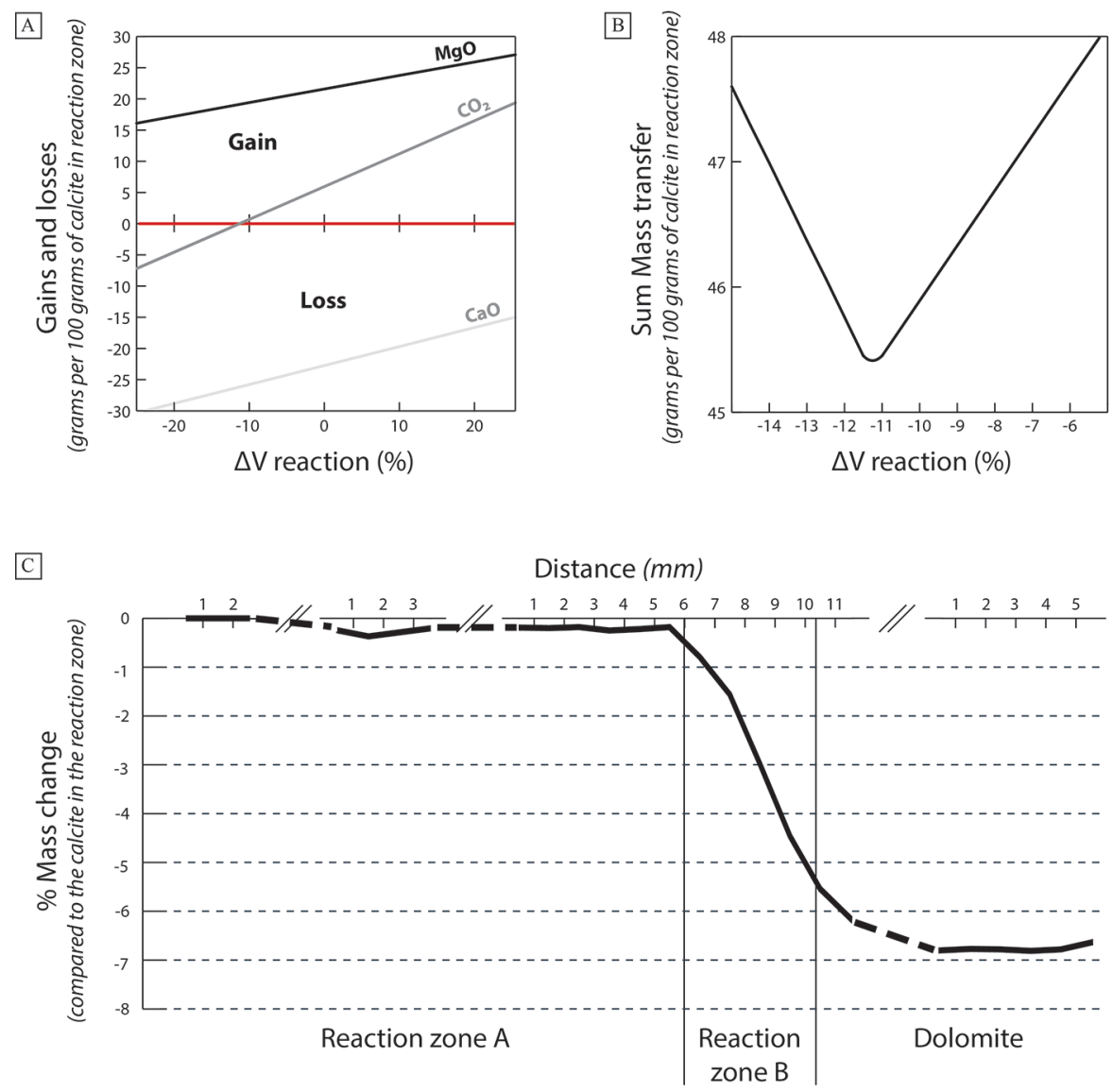

sed_12808_f9.tif 

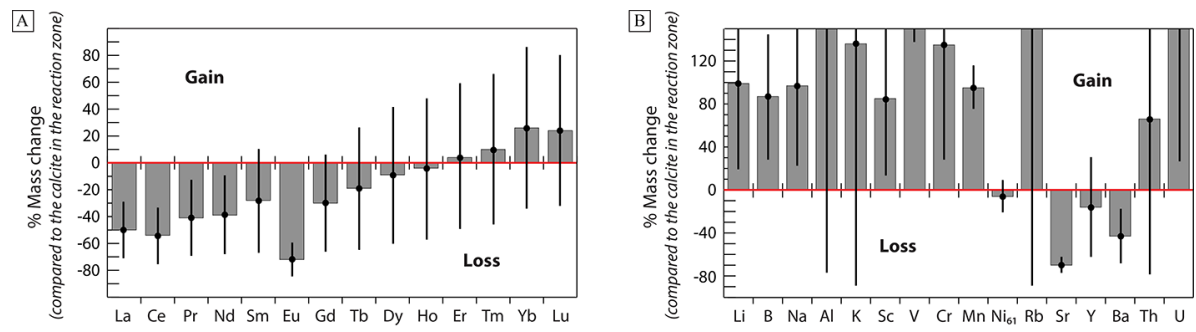

sed_12808_f10.tif 

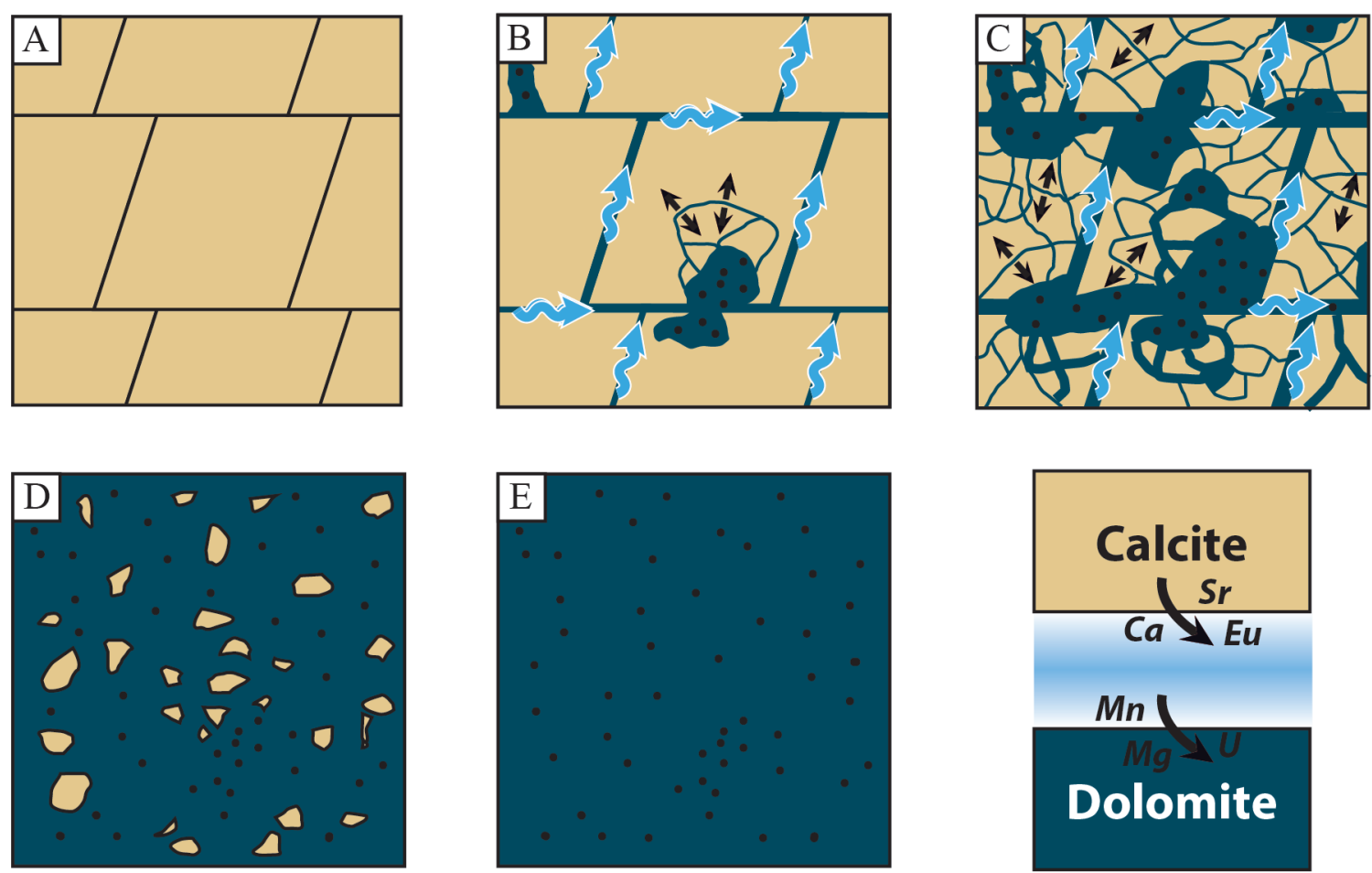

sed_12808_f11.tif 